\title{
Flood Vulnerability Assessment Using the \\ Triangular Fuzzy Number-based Analytic Hierarchy Process and Support Vector Machine Model for the Belt and Road Region
}

\section{Yu Duan}

School of Civil Engineering and Geomatics, Southwest Petroleum University, Chengdu, 640500, China https://orcid.org/0000-0002-3620-3251

Junnan Xiong ( $\triangle$ xiongjn@swpu.edu.cn )

School of Civil Engineering and Geomatics, Southwest Petroleum University, Chengdu, 640500, China; State Key Laboratory of Resources and Environmental Information System, Institute of Geographic Sciences and Natural Resources Research, CAS, Beijing, 100101, China

\section{Weiming Cheng}

State Key Laboratory of Resources and Environmental Information System, Institute of Geographic

Sciences and Natural Resources Research, CAS, Beijing, 100101, China; University of Chinese Academy of Sciences, Beijing, 100049, China

\section{Nan Wang}

State Key Laboratory of Resources and Environmental Information System, Institute of Geographic Sciences and Natural Resources Research, CAS, Beijing, 100101, China; University of Chinese Academy of Sciences, Beijing, 100049, China

Yi Li

Aerospace Information Research Institute, CAS, Beijing, 100094, China

\section{Yufeng He}

School of Civil Engineering and Geomatics, Southwest Petroleum University, Chengdu, 640500, China Jun Liu

School of Civil Engineering and Geomatics, Southwest Petroleum University, Chengdu, 640500, China

\section{Wen He}

School of Civil Engineering and Geomatics, Southwest Petroleum University, Chengdu, 640500, China

\section{Gang Yang}

School of Civil Engineering and Geomatics, Southwest Petroleum University, Chengdu, 640500, China

\section{Research Article}

Keywords: flood, vulnerability, triangular fuzzy number-based analytic hierarchy process, support vector machine, the Belt and Road region 
Posted Date: March 24th, 2021

DOI: https://doi.org/10.21203/rs.3.rs-340694/v1

License: (c) (i) This work is licensed under a Creative Commons Attribution 4.0 International License. Read Full License

Version of Record: A version of this preprint was published at Natural Hazards on July 25th, 2021. See the published version at https://doi.org/10.1007/s11069-021-04946-9. 
1 Flood Vulnerability Assessment using the Triangular Fuzzy Number-

2 Based Analytic Hierarchy Process and Support Vector Machine

3 Model for the Belt and Road Region

4 Yu Duan ${ }^{1}$, Junnan Xiong ${ }^{1,2 *}$, Weiming Cheng ${ }^{2,3}$, Nan Wang ${ }^{2,3}$, Yi Li ${ }^{4}$, Yufeng He ${ }^{1}$, Jun Liu ${ }^{1}$, Wen

$5 \quad$ He $^{1}$, Gang Yang ${ }^{1}$

61 School of Civil Engineering and Geomatics, Southwest Petroleum University, Chengdu, 640500,

7 China;

82 State Key Laboratory of Resources and Environmental Information System, Institute of Geographic

9 Sciences and Natural Resources Research, CAS, Beijing, 100101, China;

103 University of Chinese Academy of Sciences, Beijing 100049, China;

114 Aerospace Information Research Institute, CAS, Beijing 100094, China;

12

Junnan Xiong*: E-mail: xiongjn@swpu.edu.cn

Yu Duan: E-mail: 201922000658@stu.swpu.edu.cn

Weiming Cheng: E-mail: chengwm@1reis.ac.cn

Nan Wang: E-mail: wangnd.17b@igsnrr.ac.cn

Yi Li: E-mail: liyi@aircas.ac.cn

Yufeng He: E-mail: 201922000656@stu.swpu.edu.cn

Jun Liu: E-mail: 201922000655@stu.swpu.edu.cn

Wen He: E-mail: 201922000663@stu.swpu.edu.cn

Gang Yang: E-mail: 201922000664@stu.swpu.edu.cn

*Corresponding author:

Junnan Xiong 
Tel.: 86-135-4122-3403

E-mail.: xiongjn@swpu.edu.cn

Abstract: Floods are one of the most serious natural disasters. Flood disaster losses in the developing countries in the Belt and Road region are more than twice the global average. However, to date, the extent of the vulnerability of the Belt and Road Region remains poorly understood. This study sought to address this knowledge gap. In this study, the flood vulnerability throughout the Belt and Road region was evaluated by adopting the triangular fuzzy number-based analytic hierarchy process (TFN-AHP) and the support vector machine (SVM) model. According to the results, the vulnerability of most areas $\left(47,105,300 \mathrm{~km}^{2}\right)$ is low or extremely low, accounting for $93 \%$ of the Belt and Road region. The highlyvulnerable areas (accounting for 3.54\%) are primarily concentrated in the southern and eastern parts of China, northern India, most areas of Bangladesh, the Indus Valley in Pakistan, the Nile River Basin in Egypt, and the central region of Indonesia. From a local perspective, in the Belt and Road region, many major cities have higher vulnerability, such as Beijing, Shanghai, and Hong Kong. Compared with the three typical cities, the level of vulnerability in other cities (including Bangkok, Bangalore, Cairo, Riyadh, and Moscow) is lower, due to their higher disaster reduction capability. Thus, these highly vulnerable regions and cities coincide with areas characterized by frequent economic activity and dense populations.

Based on these results, this study provides scientific and technological evidence for the prevention and mitigation of flood disasters in the countries along the Belt and Road region. 
Keywords: flood; vulnerability; triangular fuzzy number-based analytic hierarchy process; support vector machine; the Belt and Road region

\section{Declarations}

We confirm that this manuscript has not been published elsewhere and is not under consideration by another journal. All authors have approved the manuscript, including authorship and order of authorship, and agree with submission to Nature Hazards.

Funding. This study is supported by Strategic Priority Research Program of the Chinese Academy of Sciences (Grant No. XDA20030302), Key R \& D project of Sichuan Science and Technology Department (Grant No. 21QYCX0016), National Flash Flood Investigation and Evaluation Project (Grant No. SHZH-IWHR-57), National Key R\&D Program of China (2020YFD1100701), and the Science and Technology Project of Xizang Autonomous Region (Grant No. XZ201901-GA-07), Project form Science and Technology Bureau of Altay Region in Yili Kazak Autonomous Prefecture.

Competing interests. The authors declare that they have no known competing financial interests or personal relationships that could have appeared to influence the work reported in this paper.

Availability of data and material. The population data are available at https://www. worldpop.org/ (last access: April 2019). The land use data are available at https:// ladsweb.modaps.eosdis.nasa.gov/ (last 
access: September 2019). The GDP data are available at https://datadryad.org/stash/dataset /doi:10.5061/dryad.dk1j0 (last access: October 2019). The data connected with infrastructure, including data from hospitals, shelters, and road density data are available at https://www.openstreetmap.org/ (last access: December 2019). The digital elevation model (DEM) data are available at http://srtm.csi. cgiar.org/srtmdata/ (last access: September 2018). The impervious surface data are available at https://ghslsys.jrc.ec.europa.eu// (last access: December 2019).

\section{Code availability. Not applicable}

Author contributions. YD, YL, and YFH were responsible for the collection and processing of the dataset. YD and JNX conceptualized the study and developed the methodology. YD and JNX were responsible for the analysis and validation of the results, and finished the original draft preparation. YD, JNX, WMC, NW, JL, WH, GY all participated in the reviewing of methodology, results, and article. All authors contributed to paper preparation and agreed to the published version of the manuscript.

\section{Introduction}

Floods rank among the most serious natural disasters in the world. Currently, floods tend to occur more frequently than other disasters, including earthquakes, forest fires, typhoons, heavy snows, and droughts (He Y-Y, Zhou J-Z, Kou P-G, Lu N, \& Zou Q 2011; Njock PGA, Shen S-L, Zhou A-N, \& Lyu H-M 2020). According to recent estimates, the economic losses caused by floods account for $40 \%$ of the 
total losses caused by all natural disasters (Xia F-Q, Kang X-W, Wu S-H, Yang Q-Y, Ma X, Yang P-G, \& Li X-D 2008). Several studies have indicated that frequent flood events have led to a worldwide increase in flood risk (Hu P, Zhang Q, Shi P-J, Chen B, \& Fang J-Y 2018; Lyu H-M, Shen S-L, Yang J, \& Yin Z-Y 2019; Lyu H-M, Shen S-L, Zhou A-N, \& Yang J 2020; Lyu H-M, Shen S-L, Zhou A-N, \& Zhou W-H 2019; Werren G, Reynard E, Lane SN, \& Balin D 2016; Wu J, Yang R, \& Song J 2018). Based on the statistics from the Emergency Disasters Database (EM-DAT, CRED, http://www.emdat. be/), in the Belt and Road region, 1,483 floods occurred from 2000 to 2020 here, accounting for $44.9 \%$ of the total floods around the world. However, most of the countries along the Belt and Road region are developing countries with underdeveloped economies and weak disaster resilience that lack the material reserves and emergency relief capabilities needed to respond to disasters (Cui P, Wu S-N, Lei Y, Zhang Z-T, \& Zou Q 2020). According to the EM-DAT, the disaster losses in the developing countries along the Belt and Road are more than twice the global average, and the death rate of people due to disasters is much higher than the global average (Ge Y-G, Cui P, \& Chen X-Q 2020). For example, between 2011 and 2013, the Philippines suffered recurrent floods that caused more than 100 fatalities per year, while India and Nepal recorded 6,648 flood fatalities in 2013. Additionally, frequent floods are a major threat to investment and engineering safety and regional development in the Belt and Road region (Ge Y-G, Cui P, \& Chen X-Q 2020). More seriously, under future climate change scenarios, the incidence and intensity of flood disasters are likely to increase significantly (Chen H-L, Ito Y, Sawamukai M, \& Tokunaga T 2015; Fang Y, Yin J, \& Wu B-H 2016; Jongman B, Ward PJ, \& Aerts JCJH 2012; Ntajal J, Lamptey BL, Mahamadou IB, \& Nyarko BK 2017). In this sense, it is of paramount importance and necessity to establish a scientific basis for flood prevention and mitigation in the Belt and Road region. 
NL 2011). Currently, in flood studies, vulnerability is most often conceptualized as a component that

consists of exposure to disturbance or external stress, sensitivity to disturbance, and the capability to adapt or the coping capacity (Adger WN 2006; Weis SWM, Agostini VN, Roth LM, Gilmer B, Schill SR,

Knowles JE, \& Blyther R 2016; Zhou S-E, Zhang M-J, \& Wang S-J 2018). Additionally, previous studies have shown that flood vulnerability is positively correlated with exposure and is negatively correlated with the disaster reduction capability (Rawat PK, Pant CC, Tiwari PC, \& Sharma PDPK 2012). coping capacity are both a measure of the physical and social nature of the carrier. Thus, a vulnerability 

historical data-based approach (Adikari Y, Osti R, \& Noro T 2010; Shi Y, Xu S-Y, \& Shi C 2011), (2) the scenario simulation method (Li Z-H, Nadim F, Huang H-W, Uzielli M, \& Lacasse S 2010; Shi Y 2013), (3) the vulnerability curve method (Zong N 2013), and (4) the index-based system (Ding M-T, Heiser M, Hubl J, \& Fuchs S 2016; Hoque MA, Tasfia S, Ahmed N, \& Pradhan B 2019). The historical data-based approach responds to the combined effects of the natural and social vulnerability and is highly practical for vulnerability distillation. However, it is directly influenced by the level of informativeness of the disaster documentation (Lyu H-M, Zhou W-H, Shen S-L, \& Zhou A-N 2020). Scenario simulation methods are based on scenario models, which are quantitative predictions. Scenario-based vulnerability analysis is typically used to predict flood vulnerability in small areas, and the application of this method is limited by the fact that floods usually occur at the regional scale (Sampson CC, Fewtrell TJ, Duncan A, Shaad K, Horritt MS, \& Bates PD 2012). As for the vulnerability curve method, it primarily focuses on assessing the relationship between the intensity of a range of hazards and the degree to which various hazard-bearing individuals are affected (Shi Y 2013). However, this method requires field statistics and questionnaires, and therefore, it is not suitable for replication and implementation on a large scale. Among these four methods, the index-based system is the most widely applied method in flood vulnerability assessment (Zhang Z-G 2014). Notably, the index-based system has the advantages of easy access to data, simple modeling and calculations, and the ability to reflect the regional vulnerability situation at a macroscopic level. Thus, the index-based system was applied in this study. To quantify the indexes more precisely, quantitative research has progressed from the investigation of a single method to that of multiple methods. Generally, these methods include multiple-criteria decision making (MCDM) 
methods (Lyu H-M, Zhou W-H, Shen S-L, \& Zhou A-N 2020) and machine learning methods (Xiong JN, Sun M, Zhang H, Cheng W-M, Yang Y-H, Sun M-Y, Cao Y-F et al. 2019). Among the MCDM methods, the triangular fuzzy number-based analytic hierarchy process (TFN-AHP) is one of the most widely used and mature approaches (Lyu H-M, Zhou W-H, Shen S-L, \& Zhou A-N 2020). Additionally, compared with other machine learning methods, the support vector machine (SVM) is a supervised machine learning technique based on statistical learning theory and the principle of structural risk minimization. The SVM not only avoids the effects of human factors, but it also expands the amount of information. Thus, in this study, the TFN-AHP and SVM were used as the quantification methods for the index-based system.

However, the knowledge base regarding large-scale flood risk and vulnerability is quite limited (Jongman B, Ward PJ, \& Aerts JCJH 2012). Traditionally, flood vulnerability assessments have been limited to national (de Moel H and Aerts JCJH 2011; Xiong J-N, Li J, Cheng W-M, Wang N, \& Guo L 2019) and even regional scales (Bouwer LM, Bubeck P, \& Aerts JCJH 2010; Lyu H-M, Zhou W-H, Shen S-L, \& Zhou A-N 2020). Based on the physical and social aspects, some scholars have conducted temporal and spatial analyses of the vulnerability of flood disasters in the United States (Cutter SL and Finch C 2008; Spitalar M, Gourley JJ, Lutoff C, Kirstetter PE, Brilly M, \& Carr N 2014). They concluded that indicator-based vulnerability assessments are a key factor in emergency preparedness, disaster mitigation planning, immediate responses, and long-term disaster recovery. At the regional scale, many studies have focused on quantitative methods of vulnerability assessments. This differs from the statistical analyses applied at the national scale. For instance, Ding et al. selected 13 index factors that included economic density, population density, building density and farmland coverage, road density, 
and GDP per capita to conduct an assessment of the debris flow vulnerability in the upper reaches of the

Min River (Ding M-T, Heiser M, Hubl J, \& Fuchs S 2016). In addition, Lyu et al. applied AHP and TFNAHP in an inundation risk assessment of the metro system in Shenzhen (Lyu H-M, Zhou W-H, Shen S-

L, \& Zhou A-N 2020). Their results showed that the TFN-AHP had a higher accuracy than AHP. Obviously, previous studies have shown that the indicator-based system is currently the dominant flood vulnerability evaluation method. However, the application of the methodologies and data used in regional studies has been difficult to apply at larger scales (Hu P, Zhang Q, Shi P-J, Chen B, \& Fang J-Y 2018; Jongman B, Ward PJ, \& Aerts JCJH 2012). In particular, most countries along the Belt and Road region are so underdeveloped and developing that they lack information sharing and international disaster reduction cooperation mechanisms, resulting in many of their fundamental data being inaccurate (Ge YG, Cui P, \& Chen X-Q 2020). Thus, research regarding the flood vulnerability in the Belt and Road region requires more in-depth investigations because this region has experienced increasing climate extremes in recent years, and the area is extremely vulnerable to flood disasters (Komolafe AA, Herath S, \& Avtar R 2019; Lugeri N, Kundzewicz ZW, Genovese E, Hochrainer S, \& Radziejewski M 2010; Sam AS, Kumar R, Kachele H, \& Muller K 2017).

Given these problems, in this study, a flood vulnerability assessment based on the need for flood disaster prevention and mitigation throughout the Belt and Road Region was conducted. The primary objectives of this study are as follows. (1) Establish an index system for evaluating the vulnerability of flood disasters throughout the Belt and Road region, including exposure and disaster reduction capability. (2) Build a new vulnerability assessment model for large-scale studies based on the triangular fuzzy number-based analytic hierarchy process (TFN-AHP) and support vector machine (SVM) to obtain the 
results of flood vulnerability assessment throughout the Belt and Road region. (3) Map and analyze the spatial characteristics of the flood exposure, disaster reduction capability, and vulnerability based on the assessment results.

\section{Materials}

\subsection{Study area}

The Belt and Road region (approximately 50,640,400 $\mathrm{km}^{2}$ ) consists of 65 countries across the Asian, European, and African continents. It contains approximately 4.4 billion people and has a combined GDP of 2.3 billion dollars, accounting for $63 \%$ and $29 \%$ of the world totals, respectively (Zhang J-D 2018). As shown in Fig. 1, this region has an undulating terrain. The highest altitude is greater than 8500 $\mathrm{m}$, while the lowest altitude is less than $0 \mathrm{~m}$. In addition, this region is dominated by eight types of climate, including both monsoons and continental climate characteristics, and the regional distribution of water resources is uneven (Zhou J, Jiang T, Wang Y-J, Su B-D, \& Zhai J-Q 2020). In terms of precipitation, the average annual total precipitation from 2000 to 2018 increased from $0.92 \mathrm{~mm}$ in the northwest to $6,067.71 \mathrm{~mm}$ in the southeast in this area. Due to the diverse natural environments, the types of terrains, and the uneven distribution of precipitation, natural disasters, especially droughts and floods, occur frequently in this area. According to the incomplete statistics from the Emergency Disasters Database (EM-DAT, CRED, http://www.emdat.be/), 1561 floods have occurred throughout the Belt and Road Region since the beginning of the 21 st century, while the number of floods from 1975 to 2000 was only 700 (Hu P, Zhang Q, Shi P-J, Chen B, \& Fang J-Y 2018). 


\subsection{Datasets and sources}

In this study, data related to the flood vulnerability were classified into four aspects: (1) The data

related to society and the economy, including population data, land use data, and GDP data. These data

surface data were collected from the Global Human Settlement Layer, GHSL

(https://ghslsys.jrc.ec.europa.eu/). Table 1 presents the characteristics of the datasets used in this study.

\subsection{Establishing the assessment index system}

\subsubsection{Assessment unit} assessment units, which are the fundamental elements of a vulnerability assessment (Cascini L 2008; Li

L-T, Xu Z-X, Pang B, \& Liu L 2012). The assessment units that previous studies have commonly used include regional units, grid units, slope units, topographic units, and uniform condition units (Liu X-L, 


\subsubsection{Index system}

After confirming the assessment unit used for this study, the assessment index system was established. Notably, the establishment of an assessment index system is a key step in building a flood vulnerability assessment. This index system was established after summarizing the results of previous studies to define the vulnerability (Ding M-T, Heiser M, Hubl J, \& Fuchs S 2016; Weis SWM, Agostini

N, \& Guo L 2019). In the numerous previous studies reviewed, vulnerability was most commonly conceptualized as a component consisting of exposure to a disturbance or external stress, sensitivity to a disturbance, and the capability to adapt (Adger WN 2006; Gallopín G 2006). In this study, the disaster reduction capability was regarded as a combination of the susceptibility and coping capacity. Therefore, the vulnerability to floods was divided into two portions: the exposure and disaster reduction capability. The exposure indexes consist of population density, economic density, building density, and farmland density. The disaster reduction capability indexes include impervious surface, dependent population, 
2, eleven assessment indexes were selected in this study.

\section{Methodology}

\subsection{Exposure assessment}

\subsubsection{Calculation of the exposure indexes}

252
According to previous studies, in areas with higher exposure, the higher the vulnerability, the greater the losses a flood will cause. Recently, several studies have divided vulnerability into two parts: physical vulnerability and social vulnerability (Erena SH and Worku H 2019; Hoque MA, Tasfia S, Ahmed N, \& Pradhan B 2019), however, other studies have only analyzed one level, the physical or social level (Rani NNVS, Satyanarayana ANV, \& Bhaskaran PK 2015; Rimba AB, Setiawati MD, Sambah AB, \& Miura F 2017; Susan L and Cutter 2003; Zhang Y-L and You W-J 2014). In this study, the primary focus was the social level. Additionally, the comprehensive impact of hazards and disasters on the environment was regarded as a threat or danger; while exposed units, such as real estate, farmland, and a human presence, were regarded as characteristics of the regional socioeconomic system (Huang JY, Liu Y, \& Ma L 2011). Thus, in this study, the population density, economic density, building density, and farmland density were used to calculate the social exposure. To some extent, because the exposure factors were measured at different scales, certain reclassifications were necessary to convert the exposure factors into five comparable units or exposure classes: 5 (extremely high exposure), 4 (high exposure), 3 (moderate exposure), 2 (low exposure), and 1 (extremely low exposure) (Mahmoud SH and Gan TY 2018). The specific indicators of exposure were defined as follows:

(1) Population density 
In this study, economic density refers to the GDP per assessment unit $\left(D=G_{i} / S_{i}\right)$, where $D$ is the economic density; $G_{i}$ is the GDP of region $i$; and $S_{i}$ represents the area of region $i$. Proverbially, the GDP is closely connected to flood disasters, and in most cases, regions with higher GDP have stronger disaster adaptation capacity, but the consequences of a flood disaster are also likely to be greater in these regions. neglecting the different heights of the buildings. 
In this study, the triangular fuzzy number-based analytic hierarchy process (TFN-AHP) was used

to calculate the exposure. In the application of the traditional AHP, since the pair comparison is based on is defined as $P$, and it can be calculated as follows:

$$
P=(l, m, \mu)(l \leq m \leq \mu)
$$

where $P$ is the triangular fuzzy number; $m$ is the most likely value; and $l$ and $\mu$ are the minimal and

maximum values, respectively. From this we can see the most probable value for $m$ is jointly determined by the parameters $l$ and $\mu$. The meaning of the triangular fuzzy number and the detailed methods of the parameter calculation have been discussed in previous studies (Lyu H-M, Shen S-L, Yang J, \& Yin Z-Y 2019; Zhang Y-L and You W-J 2014). In this study, the TFN-AHP was used to confirm the relative importance) (Table 2). In the application of the TFN-AHP, the triangular fuzzy numbers were used in the judgment matrix. 

the TFN-AHP, as shown in Table 3.

$$
\left(\begin{array}{cccccc}
{[1,1,1]} & {\left[l_{12}, m_{12}, \mu_{12}\right]} & \mathrm{L} & {\left[l_{1 i}, m_{1 i}, \mu_{1 i}\right]} & \mathrm{L} & {\left[l_{1 n}, m_{1 n}, \mu_{1 n}\right]} \\
{\left[\frac{1}{\mu_{12}}, \frac{1}{m_{12}}, \frac{1}{l_{12}}\right]} & {[1,1,1]} & \mathrm{L} & {\left[l_{2 i}, m_{2 i}, \mu_{2 i}\right]} & \mathrm{L} & {\left[l_{2 n}, m_{2 n}, \mu_{2 n}\right]} \\
{\left[\frac{1}{\mu_{1 i}}, \frac{1}{m_{1 i}}, \frac{1}{l_{1 i}}\right]} & {\left[\frac{1}{\mu_{2 i}}, \frac{1}{m_{2 i}}, \frac{1}{l_{2 i}}\right]} & \mathrm{L} & {[1,1,1]} & \mathrm{L} & {\left[l_{i n}, m_{i n}, \mu_{i n}\right]} \\
{\left[\frac{1}{\mu_{1 n}}, \frac{1}{m_{1 n}}, \frac{1}{l_{1 n}}\right]\left[\frac{1}{\mu_{2 n}}, \frac{1}{m_{2 n}}, \frac{1}{l_{2 n}}\right]} & \mathrm{L} & {\left[\frac{1}{\mu_{i n}}, \frac{1}{m_{i n}}, \frac{1}{l_{i n}}\right]} & \mathrm{L} & {[1,1,1]}
\end{array}\right)
$$

\subsection{Disaster reduction capability assessment}

\subsubsection{Calculation of the disaster reduction capability indexes}

Previous studies have suggested that the higher capability of the disaster reduction capability is,

the lower the losses caused by flood disasters will be. In a general sense, susceptibility is the degree or

the depth to which a disaster-bearing body or system is affected by a disaster of the same intensity.

Numerous studies have suggested that not all individuals and groups exposed to a hazard are equally

and Wang S-Y 2013). Therefore, data of the impervious surface, dependent populations, and female

populations were collected as susceptibility factors. In this study, the coping capability primarily relies 

namely, the hospital density, shelter density, road density and GDP per capita, were selected here. The specific indicators of the disaster reduction capacity of flood disasters were selected as follows:

\section{Susceptibility}

$$
\text { (1) Impervious surface }
$$

Urbanization has an adverse impact on the environment, especially when the urban growth rate and the carrying capacity do not co-evolve, including the management capacity, natural resources, and basic service provisions (Lee S, Okazumi T, Kwak Y, \& Takeuchi K 2015). One of the effects of urbanization is an increase in impervious surface, which makes peak discharges intense and rapid.

\section{(2) Dependent population}

In certain previous studies, children (0-15 years old) and the elderly (people over 65) were considered to be dependent people, who often need support from other groups when floods are occurring (Li L-T, Xu Z-X, Pang B, \& Liu L 2012; Sharma SVS, Roy PS, Chakravarthi V, \& Rao GS 2017). To some extent, children and the elderly often have less access to information and more difficulty in taking personal actions to prepare for floods. In this study, the index of the dependent population was produced using 2015 population data.

\section{(3) Female population}

Females are affected by floods in numerous ways due to their limited mobility and difficulty in evacuation during emergency cases (Eric N and Thomas P 2007; Hoque MA, Tasfia S, Ahmed N, \& Pradhan B 2019). Generally speaking, the female population is more vulnerable than the male population. 


\section{Coping capacity}

\section{(1) Hospital density}

The hospitals in this study refer to large hospitals in modern cities, not those in small regions. Proverbially, the higher the hospital density in a city, the higher the capacity of the people coping with floods and recovering from flood disasters. Moreover, the hospital density refers to the number of hospitals per assessment unit $\left(D=H_{i} / S_{i}\right)$, where $D$ is the hospital density; $H_{i}$ is the number of hospitals in region $i$; and $S_{i}$ represents the area of region $i$.

(2) Shelter density

In this study, shelters were defined as the emergency shelters where people can take refuge from flood disasters. The shelter density refers to the number of shelters in an assessment unit $(D=$ $\left.S h_{i} / S_{i}\right)$, where $D$ is the shelter density; $S h_{i}$ is the number of shelters in a region $i$; and $S_{i}$ denotes the area of region $i$.

(3) Road density

Here, roads primarily refer to freeways, provincial, and national highways. It is assumed that the higher the road density is, the higher the capacity of the people coping with floods will be. Road density refers to the total length of all types of roads in per an assessment unit $\left(D=R_{i} / S_{i}\right)$, where $D$ is the road density; $R_{i}$ is the total length of all roads in region $i$; and $S_{i}$ represents the area of region $i$.

(4) GDP per capita

The GDP per capita was used to evaluate the economic development level of a grid unit. Accordingly, the GDP per capita is a better indicator of the status, rate, and level of economic 
development. Generally speaking, the higher the GDP per capita is, the stronger the coping capacity population data.

\subsubsection{Support vector machine}

In this study, initially the weights in the indexes of the disaster reduction capability were not clear, and thus, the support vector machine (SVM) was used to calculate the disaster reduction capability. The SVM is a new method developed in recent years that is based on a nonlinear transformation, and it is widely used in flood risk assessment (Xian S-D 2010). Notably, the SVM is also a supervised learning binary classifier that is based on the structural risk minimization principle (Wan SA and Lei TC 2009; Yao X, Tham LG, \& Dai F-C 2008), and it can also explore the hidden relationships between inputs and outputs (Xu C, Dai F-C, Xu X-W, \& Lee YH 2012). The mechanism of a flood vulnerability assessment is complex due to the effects of incomplete information and the numerous uncertainties. To reduce the impact of these uncertainties, the SVM model was used to calculate the internal rules based on many complex fuzzy input and output variables. The primary steps of the algorithm are as follows:

(1) Assume a training set of a known sample set is $T=\left\{x_{1}, x_{2}, \ldots, x_{n}, y\right\}$, where $x_{i}$ is the $i$ th input data $x_{i}$ $\in R_{n}$, and $y$ is the output data, $i=1,2, \ldots, n$.

(2) Then, all of the data are classified into two categories, and n-dimensional hyperplanes are used to obtain the maximum interval. This is demonstrated in Eq. (3) and (4).

$$
\frac{1}{2}\|w\|^{2}
$$

$$
\text { Subject to } y_{i}\left(\left(w \cdot x_{i}\right)+b\right) \geq 1
$$


(3) With the use of the Lagrange multiplier, the definition of the cost function is as follows:

$$
L=\frac{1}{2}\|w\|^{2}-\sum_{i=1}^{n} \lambda_{i}\left(y_{i}\left(\left(w \cdot x_{i}\right)+b\right)-1\right)
$$

(4) For inseparable situations, the constraint conditions can be modified by introducing slack variables,

$$
y_{i}\left(\left(w \cdot x_{i}\right)+b\right) \geq 1-\xi_{i}
$$

Therefore, Eq. (7) becomes

where $v \in(0,1]$, which is introduced to explain the misclassification (Franklin J 2005; Xu C, Dai F-C,

Xu X-W, \& Lee YH 2012).

In this study, a kernel function, $K\left(x_{i}, x_{j}\right)$, was used to make the nonlinear decision boundary clear

(Cherkassky V 1997). In recent studies, the linear kernel (LN), the polynomial kernel (PL), the sigmoid

The RBF was used in this study:

$$
K\left(x_{i}, x_{j}\right)=e^{-\gamma\left(x_{i}-x_{j}\right)^{2}}, \gamma>0
$$

where $\gamma$ is a parameter of the kernel function. 


\subsection{Vulnerability assessment}

Previous studies have verified that flood vulnerability is positively correlated with the degree of exposure and is negatively correlated with the disaster reduction capability (Ding M-T, Heiser M, Hubl

\subsection{Assessment procedure}


using the R software. In the third phase, based on the vulnerability obtained using Eq. (9), the results of the flood vulnerability were mapped, and a spatial analysis was conducted.

\section{Results}

\subsection{Exposure assessment}

In this study, in order to intuitively quantify the results, the results of the exposure were placed into 646,191 grid cells. As is illustrated Table 4, the statistical results of each level of the quantity, area, and proportion in the exposure assessment can be seen. It was discovered that most of the regions $(43,781,500$ $\mathrm{km}^{2}$ ) have extremely low exposure, accounting for approximately $86 \%$ of the total area. The area of the low exposure regions is $3,446,200 \mathrm{~km}^{2}$, which is larger than the entire area of India. Furthermore, 25,977 grid cells $\left(2,035,700 \mathrm{~km}^{2}\right)$ have moderate exposure, 13,053 grid cells $\left(1,021,100 \mathrm{~km}^{2}\right)$ have high exposure, and 4523 grid cells $\left(355,900 \mathrm{~km}^{2}\right)$ have extremely high exposure, accounting for approximately $0.70 \%$.

As shown in Fig. 4, a map of the flood exposure throughout the Belt and Road region was produced. It can be seen that most of the areas have extremely low and low exposure. However, in this analysis, our attention was focused more on those areas with higher exposure, which are likely to suffer more economic and population losses when floods occur. In summary, Fig. 4 shows that the higher exposure areas are primarily located in the eastern and southern parts of Asia, including eastern China, northern India, the Indus Valley in Pakistan, the central region of Indonesia, and most of Bangladesh. Locally, the extremely high exposure areas are primarily distributed in the capitals and major cities of the countries in the Belt and Road region, such as Beijing, Shanghai, Chengdu, New Delhi, Bangkok, Jakarta, Moscow, 
Abu, Riyadh, Kyiv, Baghdad, and Cairo. Obviously, these areas of higher exposure are densely populated and economically developed. This is consistent with the larger proportions of the population density and economic density in the exposure indicators.

\subsection{Disaster reduction capability assessment}

The statistical results of each level of the quantity, area, and proportion of the disaster reduction capability are presents in Table 5. It was found that in most regions, the disaster reduction capability is extremely low $\left(407,853,000 \mathrm{~km}^{2}\right)$ and low $\left(7,869,200 \mathrm{~km}^{2}\right)$, accounting for $80.53 \%$ and $15.54 \%$ of the total area, respectively. The areas with moderate disaster reduction capability merely only account for $3.26 \%$. Notably, the areas with high and extremely high disaster reduction capacity both account for less than $1 \%$ of the total area. There are only 3,683 grid cells $\left(287,200 \mathrm{~km}^{2}\right)$ and 648 grid cells $\left(49,300 \mathrm{~km}^{2}\right)$ with high and extremely high disaster reduction capability, accounting for $0.57 \%$ and $0.10 \%$, respectively.

As for the spatial distribution patterns, Fig. 5 shows that more than half of the areas have low disaster reduction capability, which is consistent with the above results. The areas with moderate disaster reduction capability are primarily located in the western and eastern parts of the Belt and Road region. Among these areas, only a portion are distributed in eastern China, southern Nepal, the central region of Indonesia and the Cairo region of Egypt, and the vast majority are concentrated in most of the regions of Europe. Notably, there few areas have high disaster reduction capability. As shown in Fig. 5, these areas are mainly concentrated in the major cities in the Belt and Road region, such as Beijing, Shanghai, Hong Kong, Taipei, Bangkok, Jakarta, New Delhi, Riyadh, Abu Dhabi, Cairo, Moscow, and several major cities in Europe. 


\subsection{Vulnerability assessment}

According to the assessment results of the exposure and disaster reduction capability, the vulnerability of each grid cell was calculated using Eq. (9). The statistical results of each grade of the quantity, area, and proportion of the vulnerability are presented in Table 6 . As can be seen, vulnerability of most regions $\left(43,817,500 \mathrm{~km}^{2}\right)$ is extremely low, accounting for $86.53 \%$ of the total area. Furthermore, 41,938 grid cells $\left(3,287,800 \mathrm{~km}^{2}\right)$ have low vulnerability, and 22,229 grid cells $\left(1,744,200 \mathrm{~km}^{2}\right)$ have moderate vulnerability. The areas with high and extremely high vulnerabilities, with disaster distribution densities of $1,236,100$ and $554,800 \mathrm{~km}^{2}$, respectively, account for 2.36 and $1.19 \%$ of the total area, respectively.

According to Eq. (9), the vulnerability to floods is positively related to the exposure and negatively related to the disaster reduction capability. Similar to the distribution of the exposure, most areas have low and extremely low vulnerability, occupying most of the proportion of the Belt and Road region (Fig. 6). In addition, the areas with high and extremely high vulnerability are primarily distributed in the southern and eastern parts of China, northern India, most of Bangladesh, the Indus Valley in Pakistan, the Nile River Basin in Egypt, the central region of Indonesia, and major cities in the Belt and Road region. These highly vulnerable areas coincide with the areas characterized by frequent economic activities and dense populations, such as eastern China and northern India, in particular. In contrast to the positive correlation between the exposure and vulnerability, the disaster reduction capability decreases the vulnerability to floods. Thus, those areas with higher disaster reduction capability have lower-levels of vulnerability, such as Bangkok of Thailand, Kuala Lumpur of Malaysia, Riyadh in the 


\section{Discussion}

\subsection{Assessment methodology}

In this study, a multi-dimensional analysis of the indexes used to calculate the flood vulnerability throughout the Belt and Road region was proposed. Regarding the vulnerability to flood disasters, several previous studies have emphasized the importance of quantifying the exposure and disaster reduction capability (Kim ES and Choi HI 2011; Li Z-H, Nadim F, Huang H-W, Uzielli M, \& Lacasse S 2010; Xiong J-N, Li J, Cheng W-M, Wang N, \& Guo L 2019). Thus, the model was extended to a more comprehensive assessment of the flood vulnerability of the Belt and Road region, and it included social exposure, susceptibility, and coping capacity. Based on the index-based system, we conducted a flood vulnerability assessment of the Belt and Road region. In vulnerability assessments, the AHP is one of the most commonly used weighting methods. By applying the AHP, all of the factors are compared in pairs based on the opinions of the decision makers. However, the final weight obtained is a certain number, causing the resulting values to represent their relative importance, which is subjective (Mahmoud $\mathrm{SH}$ and Gan TY 2018). Compared with the AHP, the TFN-based weight is a triangular fuzzy number, not a definite number, which can reduce the impact of these subjectivities on the vulnerability assessment (Lyu of the triangular fuzzy number denotes the largest probability of the evaluation model, while the minimum and maximum values represent the ambiguity corresponding to the largest probability (Cheng 
X, Tham LG, \& Dai F-C 2008). Currently, the SVM is widely used in flood disaster assessment studies.

Compared with previous models, the support vector machine (SVM) method not only avoids the effects of human factors, but it also expands the amount of information (Xiong J-N, Li J, Cheng W-M, Wang N, \& Guo L 2019). negatively correlated with the disaster reduction capability, which is consistent with the results of previous studies (Ding M-T, Heiser M, Hubl J, \& Fuchs S 2016; Xiong J-N, Li J, Cheng W-M, Wang N, \& Guo L 2019). In fact, there is no vulnerability when the exposure is equal to 0 because "a hazard is not hazardous unless it threatens something; [and] vulnerability does not exist unless some elements at risk are threatened by something”(Ding M-T, Heiser M, Hubl J, \& Fuchs S 2016). During the assessment procedure, the weights of the assessment indexes have an important influence on the assessment result. 
Notably, the population density and economic density are key indexes of exposure, while the other indexes are less important (Table 3) (Ding M-T, Heiser M, Hubl J, \& Fuchs S 2016). As shown in Fig. 4, the spatial pattern of the exposure shows that areas with higher population density and higher GDP have a higher exposure to flood disasters (Ding M-T, Heiser M, Hubl J, \& Fuchs S 2016; Hoque MA, Tasfia eastern parts of China, northern India, and the central region of Indonesia, due to the impact of their dense populations and high economic densities (An Y, Tan X-C, Gu B-H, \& Zhu K-W ; Cui P, Wu S-N, Lei Y, Zhang Z-T, \& Zou Q 2020), the exposure of these regions is relatively higher. In contrast to other areas, numerous capitals and major cities of these countries along the Belt and Road region have higher

exposure, for example, Beijing, Shanghai, Guangzhou, Chengdu, Taipei, Hanoi, Manila, Bangkok, Bandung, New Delhi, Kolkata, Dhaka, Moscow, Cairo, and Abu Dhabi (Fig. 4). This is because capitals are often the political, economic, and cultural centers of their countries. In contrast, the exposure of most of the areas of the Belt and Road region is low and extremely low (Fig. 4), accounting for approximately $47,227,700 \mathrm{~km}^{2}$ totally (Table 4). The reason for this phenomenon is that the maximum and minimum values of these indicators vary too much, although all of the exposure indicators were normalized and reclassified.

With respect to the disaster reduction capability, our findings indicate that the disaster reduction capability of most areas of the Belt and Road region is low, which is corresponds to the results of Ge (Ge Y-G, Cui P, \& Chen X-Q 2020) and Cui (Cui P, Wu S-N, Lei Y, Zhang Z-T, \& Zou Q 2020), who also demonstrated the weak disaster prevention and mitigation capabilities throughout the Belt and Road region. As shown in Fig. 5, most of the areas of the Belt and Road have extremely low $\left(40,785,300 \mathrm{~km}^{2}\right)$ 
and low $\left(7,869,200 \mathrm{~km}^{2}\right)$ disaster reduction capability, accounting for $80.53 \%$ and $15.54 \%$ of the total

area, respectively (Table 5). Notably, most of the countries in this region have underdeveloped economies, low levels of education, and high population densities, which leads to their overall disaster prevention and resilience capabilities being weak (Cui P, Wu S-N, Lei Y, Zhang Z-T, \& Zou Q 2020). In contrast, the more developed cities and regions have higher disaster reduction capability, such as Beijing, Shanghai, Chengdu, Guangzhou, Taipei, Hanoi, Bangkok, Kuala Lumpur, Dhaka, New Delhi, Moscow and Abu Dhabi. Regionally, the areas with higher disaster reduction capability are primarily distributed in the European countries, while a small amount is located in eastern China, the central region of Indonesia, the Cairo region of Egypt, and several cities in western Russia (Fig. 5). The people in these areas can respond quickly to losses and have a strong resistance to flood disasters (Jongman B, Ward PJ, \& Aerts JCJH 2012; Okazawa Y, Yeh PJF, Kanae S, \& Oki T 2011). In addition, the spatial patterns of the disaster reduction capability reveal that the areas with high hospital densities, high shelter densities, high road densities and high GDP per capita have a lower incidence of flood disasters (Hoque MA, Tasfia S, Ahmed N, \& Pradhan B 2019), especially in the European countries (Fig. 5).

The results presented here support some of the important findings of previous studies. Similar to the observations reported in several studies (Liu J-F, Wang X-Q, Zhang B, Li J, Zhang J-Q, \& Liu X-Q 2017; Liu Y-S, Yang Z-S, Huang Y-H, \& Liu C-J 2018), the resulting vulnerability throughout the Belt and Road region (Fig. 6) indicates that the distribution characteristics of the vulnerability are similar to that of the population density and GDP. In general, the spatial distribution of the vulnerability (Fig. 6) is similar to that of the exposure (Fig. 4), which is in agreement with Eq. (9). Compared to earlier models, which calculate vulnerability through the direct addition of the exposure, susceptibility, and coping 
capacity, the information used in the approach proposed in this study is expanded (Ding M-T, Heiser M, Hubl J, \& Fuchs S 2016). As can be seen Fig. 6, the vulnerability of most of the regions $\left(43,817,500 \mathrm{~km}^{2}\right)$ is extremely low, accounting for $86.53 \%$ of the total area. Regionally, those areas with extremely high vulnerability are primarily distributed in eastern China, northern India, the Indus Valley in Pakistan, and most of Bangladesh, which are densely populated and economically concentrated. When these areas suffer from floods, the deaths and economic losses will be more severe than in other areas. Additionally, the level of vulnerability in many major cities (Fig. 6) is lower than that of the exposure (Fig. 4) due to their higher disaster reduction capabilities (Xiong J-N, Li J, Cheng W-M, Wang N, \& Guo L 2019). As shown in Fig. 6, the typical regions and major cities are Bangkok, Kuala Lumpur, Bangalore, Cairo, Riyadh, Moscow, and Kyiv. Here, the response to floods mainly depends on the various flood defense structures. However, several studies have illustrated that there will be many difficulties in mitigating flood vulnerability if people only rely on flood defense structures. Methods, such as "living with rivers" and "making space for water", not only provide space for storing flood water, but also protect natural habitats (Johnson C, Penning-Rowsell E, \& Tapsell S 2007). Future research should consider these aspects.

Overall, these results can help people understand which areas in the Belt and Road region are most threatened by flood disasters and which areas have better disaster reduction capabilities. Furthermore, these maps can help the governments of the countries in the Belt and Road region organize and project the future layout of populations, economies, cities, roads, and other infrastructure. 


\subsection{Importance and limitations}

The United Nations Disaster Reduction Agency (UNISDR, 2011) recently stated that the exposure

of economies affected by floods is increasing in all regions of the world, while the risk of death in developed countries is declining due to increased income and improved governance (such as emergency planning and preparations) (Jongman B, Ward PJ, \& Aerts JCJH 2012). However, most of the countries in the Belt and Road region are developing countries, and their disaster prevention and mitigation foundations and abilities are weak due to limited levels of economic, social, technological and educational development (Ge Y-G, Cui P, \& Chen X-Q 2020). In addition, these countries are focusing more on building their economies, while they are ignoring the construction of disaster prevention and mitigation systems (Gray C and Mueller V 2012; Jongman B, Ward PJ, \& Aerts JCJH 2012; Tanoue M, Hirabayashi Y, \& Ikeuchi H 2016). In the cities and regions that are more susceptible to disasters, regardless of whether the risks are to human lives or the economy, the prevention and mitigation of floods should be emphasized. Subsequently, flood awareness should be increased to help deal with flood risks in a sustainable way (Johnson C, Penning-Rowsell E, \& Tapsell S 2007). Currently, more reliable vulnerability studies need to be conducted for the entire Belt and Road region, and this study contributes to this need.

Despite progress being made via this study, there are limitations to this study. Initially, a larger resolution was considered for use, e.g., $1 \times 1 \mathrm{~km}$ or $0.5 \times 0.5 \mathrm{~km}$ (Ding M-T, Heiser M, Hubl J, \& Fuchs $\mathrm{S}$ 2016), but later it was found that there were hundreds of millions of grids corresponding to these resolutions, which was a huge test for the experimental equipment used. Regrettably, we only conducted 

set of metrics to measure flood vulnerability, because different scholars have different understandings of consider the influences of these factors, and this aspect should prove to be an interesting topic.

\section{Conclusions} densities, more built-up land, and relatively developed economies. Additionally, the results of the disaster reduction capability assessment suggest that the disaster reduction capabilities of the countries along the Belt and Road are inextricably linked to their socio-economic development. The higher disaster reduction capability areas are mainly concentrated in the major cities in the Belt and Road region, including Beijing, 
624

625

626

627

628

629

630

631

of the exposure and disaster reduction capability results, the vulnerability assessment was calculated using Eq. (9). According to the results, most of the areas of the Belt and Road region $\left(47,105,300 \mathrm{~km}^{2}\right)$ have extremely low and low vulnerability, approximately accounting for $93 \%$ of the total area. The highly-vulnerable areas (accounting for 3.54\%) are primarily distributed in southern and eastern China, northern India, most of Bangladesh, the Indus Valley in Pakistan, the Nile River Basin in Egypt, the central region of Indonesia, and the major cities in the Belt and Road region. Obviously, these highly vulnerable regions and cities coincide with the areas that are characterized by frequent economic activities and dense populations, indicating that areas with high populations and economic densities may be more susceptible to flood disasters in the future. Although this study has limitations in terms of the temporal scale and spatial resolution, the results for the high-vulnerability regions will hopefully encourage local government officials to pay attention to "hot spots" where more accurate analyses need to be conducted.

\section{Acknowledgments}

This study is supported by Strategic Priority Research Program of the Chinese Academy of Sciences (Grant No. XDA20030302), Key R \& D project of Sichuan Science and Technology Department (Grant No. 21QYCX0016), National Flash Flood Investigation and Evaluation Project (Grant No. SHZH-IWHR-57), National Key R\&D Program of China (2020YFD1100701), and the Science and Technology Project of Xizang Autonomous Region (Grant No. XZ201901-GA-07), Project form Science and Technology Bureau of Altay Region in Yili Kazak Autonomous Prefecture. The authors are grateful to this support.

\section{References}

Adger WN. (2006). Vulnerability. Global Environmental Change, 16(3), 268-281. 
https://dx.doi.org/10.1016/j.gloenvcha.2006.02.006

Adikari Y, Osti R, \& Noro T. (2010). Flood-related disaster vulnerability: an impending crisis of megacities in Asia. Journal of Flood Risk Management, 3(3), 185-191. https://dx.doi.org/10.1111/j.1753-318X.2010.01068.x

An Y, Tan X-C, Gu B-H, \& Zhu K-W. Flood risk assessment using the CV-TOPSIS method for the Belt and Road Initiative: an empirical study of Southeast Asia. Ecosystem Health and Sustainability, 6(1). https://dx.doi.org/10.1080/20964129.2020.1765703

Bodoque JM, Amerigo M, Díez-Herrero A, et al. (2016). Improvement of resilience of urban areas by integrating social perception in flash-flood risk management. Journal of Hydrology, 541, 665-676. https://dx.doi.org/10.1016/j.jhydrol.2016.02.005

Bouwer LM, Bubeck P, \& Aerts JCJH. (2010). Changes in future flood risk due to climate and development in a Dutch polder area. Global Environmental Change, 20(3), 463-471. https://dx.doi.org/10.1016/j.gloenvcha.2010.04.002

Bui DT, Pradhan B, Lofman O, \& Revhaug I. (2012). Landslide Susceptibility Assessment in Vietnam Using Support Vector Machines, Decision Tree, and Naive Bayes Models. Mathematical Problems in Engineering, 2012, 26. https://dx.doi.org/10.1155/2012/974638

Cascini L. (2008). Applicability of landslide susceptibility and hazard zoning at different scales. Engineering Geology, 102(3-4), 164-177. https://dx.doi.org/10.1016/j.enggeo.2008.03.016

Chen H-L, Ito Y, Sawamukai M, \& Tokunaga T. (2015). Flood hazard assessment in the Kujukuri Plain of Chiba Prefecture, Japan, based on GIS and multicriteria decision analysis. Natural Hazards, 78(1), 105-120. https://dx.doi.org/10.1007/s11069-015-1699-5

Cheng Z-L, Zhou W-H, \& Garg A. (2020). Genetic programming model for estimating soil suction in shallow soil layers in the vicinity of a tree. Engineering Geology, 268, 105506. https://doi.org/10.1016/j.enggeo.2020.105506

Cherkassky V. (1997). The Nature Of Statistical Learning Theory. IEEE Transactions on Neural Networks, 8(6), 1564-1564. https://dx.doi.org/10.1109/TNN.1997.641482

Cui P, Wu S-N, Lei Y, Zhang Z-T, \& Zou Q. (2020). Disaster risk management pattern alongthe Belt and Roadregions. Science \& Technology Review, 38(16), 35-44. https://dx.doi.org/10.3981/j.issn.1000-7857.2020.16.004

Cutter SL, \& Finch C. (2008). Temporal and spatial changes in social vulnerability to natural hazards. Proceedings of the National Academy of ences, 105(7), 23012306. https://dx.doi.org/10.1073/pnas.0710375105

de Moel H, \& Aerts JCJH. (2011). Effect of uncertainty in land use, damage models and inundation depth on flood damage estimates. Natural Hazards, 58(1), 407425. https://dx.doi.org/10.1007/s11069-010-9675-6 
Ding M-T, Heiser M, Hubl J, \& Fuchs S. (2016). Regional vulnerability assessment for debris flows in China-a CWS approach. Landslides, 13(3), 537-550. https://dx.doi.org/10.1007/s10346-015-0578-1

Erena SH, \& Worku H. (2019). Urban flood vulnerability assessments: the case of Dire Dawa city, Ethiopia. Natural Hazards, 97(2), 495-516. https://dx.doi.org/10.1007/s11069-019-03654-9

Eric N, \& Thomas P. (2007). The Gendered Nature of Natural Disasters: The Impact of Catastrophic Events on the Gender Gap in Life Expectancy, 1981-2002. Annals of the American Association of Geographers, 97(3), 551-566. https://dx.doi.org/10.1111/j.1467-8306.2007.00563.x

Fang Y, Yin J, \& Wu B-H. (2016). Flooding risk assessment of coastal tourist attractions affected by sea level rise and storm surge: a case study in Zhejiang Province, China. Natural Hazards, 84(1), 611-624. https://dx.doi.org/10.1007/s11069016-2444-4

Fekete A. (2012). Spatial disaster vulnerability and risk assessments: challenges in their quality and acceptance. Natural Hazards, 61(3), 1161-1178. https://dx.doi.org/10.1007/s11069-011-9973-7

Franklin J. (2005). The elements of statistical learning: data mining, inference and prediction. The Mathematical Intelligencer, 27(2), 83-85. https://dx.doi.org/10.1007/BF02985802

Fraser EDG, Dougill AJ, Mabee WE, Reed M, \& Mcalpine P. (2006). Bottom up and top down: analysis of participatory processes for sustainability indicator identification as a pathway to community empowerment and sustainable environmental management. Journal of Environmental Management, 78(2), 114-127. https://dx.doi.org/10.1016/j.jenvman.2005.04.009

Gallopín G. (2006). Linkages between vulnerability, resilience, and adaptive capacity. Global Environmental Change, 16(3), 293-303. https://dx.doi.org/10.1016/j.gloenvcha.2006.02.004

Ge Y-G, Cui P, \& Chen X-Q. (2020). Strategy of the international cooperation with respect to disaster prevention and reduction in the Belt and Road areas. Science \& Technology Review, 38(16), 29-34. https://dx.doi.org/10.3981/j.issn.10007857.2020.16.003

Gray C, \& Mueller V. (2012). Drought and Population Mobility in Rural Ethiopia. World Development, 40(1), 134-145. https://doi.org/10.1016/j.worlddev.2011.05.023

He Y-Y, Zhou J-Z, Kou P-G, Lu N, \& Zou Q. (2011). A fuzzy clustering iterative model using chaotic differential evolution algorithm for evaluating flood disaster. Expert Systems with Applications, 38(8), 10060-10065. https://doi.org/10.1016/j.eswa.2011.02.003

Hoque MA, Tasfia S, Ahmed N, \& Pradhan B. (2019). Assessing Spatial Flood Vulnerability at Kalapara Upazila in Bangladesh Using an Analytic Hierarchy 
Process. Sensors, 19(6), 1302. https://dx.doi.org/10.3390/s19061302

Hu P, Zhang Q, Shi P-J, Chen B, \& Fang J-Y. (2018). Flood-induced mortality across the globe: Spatiotemporal pattern and influencing factors. Science of The Total Environment, 643, 171-182. https://doi.org/10.1016/j.scitotenv.2018.06.197

Huang J-Y, Liu Y, \& Ma L. (2011). Assessment of regional vulnerability to natural hazards in China using a DEA model. International Journal of Disaster Risk ence, 2(2), 41-48. https://dx.doi.org/10.1007/s13753-011-0010-y

Janssen MA, Schoon ML, Ke W, \& Börner K. (2006). Scholarly networks on resilience, vulnerability and adaptation within the human dimensions of global environmental change. Global Environmental Change, 16(3), 240-252. https://doi.org/10.1016/j.gloenvcha.2006.04.001

Johnson C, Penning-Rowsell E, \& Tapsell S. (2007). Aspiration and reality: flood policy, economic damages and the appraisal process. Area, 39(2), 214-223. https://dx.doi.org/10.1111/j.1475-4762.2007.00727.x

Jongman B, Ward PJ, \& Aerts JCJH. (2012). Global exposure to river and coastal flooding: Long term trends and changes. Global Environmental Change, 22(4), 823-835. https://doi.org/10.1016/j.gloenvcha.2012.07.004

Kim ES, \& Choi HI. (2011). Assessment of Vulnerability to Extreme Flash Floods in Design Storms. International Journal of Environmental Research \& Public Health, 8(7), 2907-2922. https://dx.doi.org/10.3390/ijerph8072907

Komolafe AA, Herath S, \& Avtar R. (2019). Establishment of detailed loss functions for the urban flood risk assessment in Chao Phraya River basin, Thailand. Geomatics Natural Hazards \& Risk, 10(1), 633-650. https://dx.doi.org/10.1080/19475705.2018.1539038

Kummu M, Taka M, \& Guillaume JHA. (2018). Data Descriptor: Gridded global datasets for Gross Domestic Product and Human Development Index over 1990-2015. Scientific Data, 5, 15. https://dx.doi.org/10.1038/sdata.2018.4

Lee S, Okazumi T, Kwak Y, \& Takeuchi K. (2015). Vulnerability proxy selection and risk calculation formula for global flood risk assessment: a preliminary study. Water Policy, 17(1), 8. https://dx.doi.org/10.2166/wp.2014.158

Li L-T, Xu Z-X, Pang B, \& Liu L. (2012). Flood risk zoning in China. Journal of Hydraulic Engineering, 22-30. https://dx.doi.org/10.13243/j.cnki.slxb.2012.01.001

Li Z-H, Nadim F, Huang H-W, Uzielli M, \& Lacasse S. (2010). Quantitative vulnerability estimation for scenario-based landslide hazards. Landslides, 7(2), 125-134. https://dx.doi.org/10.1007/s10346-009-0190-3

Liu J-F, Wang X-Q, Zhang B, Li J, Zhang J-Q, \& Liu X-Q. (2017). Storm flood risk zoning in the typical regions of Asia using GIS technology. Natural Hazards, 87(3), 1691-1707. https://dx.doi.org/10.1007/s11069-017-2843-1

Liu J, \& Wang S-Y. (2013). Analysis of human vulnerability to the extreme rainfall event on 21-22 July 2012 in Beijing, China. Natural Hazards Earth System 
Science, 13(11), 2911-2926. https://dx.doi.org/10.5194/nhess-13-2911-2013

Liu X-L, Cheng M, \& Tian C-S. (2017). Comparative Analysis of Two Methods for Assessing Hazard of Landslide and Debris-flow on a Regional Scale. Journal of Disaster Prevention Mitigation Engineering. https://dx.doi.org/10.13409/j.cnki.jdpme.2017.01.010

Liu X-L, \& Lei J-Z. (2003). A method for assessing regional debris flow risk: an application in Zhaotong of Yunnan province (SW China). Geomorphology. https://dx.doi.org/10.1016/S0169-555X(02)00242-8

Liu Y-S, Yang Z-S, Huang Y-H, \& Liu C-J. (2018). Spatiotemporal evolution and driving factors of China's flash flood disasters since 1949. Science China-Earth Sciences, 61(12), 1804-1817. https://dx.doi.org/10.1007/s11430-017-9238-7

Liverman D, \& O'Brien K. (1991). Global warming and climate change in Mexico. Global Environmental Change, 1(5), 351-364. https://dx.doi.org/10.1016/09593780(91)90002-B

Lugeri N, Kundzewicz ZW, Genovese E, Hochrainer S, \& Radziejewski M. (2010). River flood risk and adaptation in Europe-assessment of the present status. Mitigation and Adaptation Strategies for Global Change, 15(7), 621-639. https://dx.doi.org/10.1007/s11027-009-9211-8

Lyu H-M, Shen S-L, Yang J, \& Yin Z-Y. (2019). Inundation analysis of metro systems with the storm water management model incorporated into a geographical information system: a case study in Shanghai. HYDROLOGY AND EARTH SYSTEM SCIENCES, 23(10), 4293-4307. https://dx.doi.org/10.5194/hess-234293-2019

Lyu H-M, Shen S-L, Zhou A-N, \& Yang J. (2020). Risk assessment of mega-city infrastructures related to land subsidence using improved trapezoidal FAHP. Science of The Total Environment, 717, 135310. https://doi.org/10.1016/j.scitotenv.2019.135310

Lyu H-M, Shen S-L, Zhou A-N, \& Zhou W-H. (2019). Flood risk assessment of metro systems in a subsiding environment using the interval FAHP-FCA approach. Sustainable Cities and Society, 50, 101682. https://doi.org/10.1016/j.scs.2019.101682

Lyu H-M, Zhou W-H, Shen S-L, \& Zhou A-N. (2020). Inundation risk assessment of metro system using AHP and TFN-AHP in Shenzhen. Sustainable Cities, 56, 102103. https://dx.doi.org/10.1016/j.scs.2020.102103

Mahmoud SH, \& Gan TY. (2018). Multi-criteria approach to develop flood susceptibility maps in arid regions of Middle East. Journal of Cleaner Production, 196, 216-229. https://dx.doi.org/10.1016/j.jclepro.2018.06.047

Malone EL, \& Engle NL. (2011). Evaluating regional vulnerability to climate change: purposes and methods. Wiley Interdisciplinary Reviews Climate Change, 2(3), 462-474. https://dx.doi.org/10.1002/wcc.116

Metzger MJ, Rounsevell MDA, Acosta-Michlik L, Leemans R, \& Schröter D. (2006). 
The Vulnerability of Ecosystem Services to Land Use Change. Agriculture $\begin{array}{llll}\text { Ecosystems \& } \quad \text { Environment, } & \text { 114(1), }\end{array}$ https://dx.doi.org/10.1016/j.agee.2005.11.025

Njock PGA, Shen S-L, Zhou A-N, \& Lyu H-M. (2020). Evaluation of soil liquefaction using AI technology incorporating a coupled ENN / t-SNE model. Soil Dynamics and Earthquake Engineering, 130, 105988. https://doi.org/10.1016/j.soildyn.2019.105988

Ntajal J, Lamptey BL, Mahamadou IB, \& Nyarko BK. (2017). Flood disaster risk mapping in the Lower Mono River Basin in Togo, West Africa. International Journal of Disaster Risk Reduction, 23, 93-103. https://doi.org/10.1016/j.ijdrr.2017.03.015

Okazawa Y, Yeh PJF, Kanae S, \& Oki T. (2011). Development of a global flood risk index based on natural and socio-economic factors. International Association of entific Hydrology Bulletin, 56(5), 789-804. https://dx.doi.org/10.1080/02626667.2011.583249

Rana IA, \& Routray JK. (2018). Integrated methodology for flood risk assessment and application in urban communities of Pakistan. Natural Hazards, 91(1), 239 266. https://dx.doi.org/10.1007/s11069-017-3124-8

Rani NNVS, Satyanarayana ANV, \& Bhaskaran PK. (2015). Coastal vulnerability assessment studies over India: a review. Natural Hazards, 77(1), 405-428. https://dx.doi.org/10.1007/s11069-015-1597-x

Rawat PK, Pant CC, Tiwari PC, \& Sharma PDPK. (2012). Spatial variability assessment of river-line floods and flash floods in Himalaya. Disaster Prevention Management, 21(2), 135-159. http://dx.doi.org/10.1108/09653561211219955

Rimba AB, Setiawati MD, Sambah AB, \& Miura F. (2017). Physical Flood Vulnerability Mapping Applying Geospatial Techniques in Okazaki City, Aichi $\begin{array}{llll}\text { Prefecture, Japan. Urban } & \text { Science, }\end{array}$ https://dx.doi.org/10.3390/urbansci1010007

Sam AS, Kumar R, Kachele H, \& Muller K. (2017). Vulnerabilities to flood hazards among rural households in India. Natural Hazards, 88(2), 1133 -1153. https://dx.doi.org/10.1007/s11069-017-2911-6

Sampson CC, Fewtrell TJ, Duncan A, Shaad K, Horritt MS, \& Bates PD. (2012). Use of terrestrial laser scanning data to drive decimetric resolution urban inundation models. Advances in Water Resources, 41, 1-17. https://dx.doi.org/10.1016/j.advwatres.2012.02.010

Sharma SVS, Roy PS, Chakravarthi V, \& Rao GS. (2017). Flood risk assessment using multi-criteria analysis: a case study from Kopili River Basin, Assam, India. Geomatics Natural Hazards Risk(1), 1-15. https://dx.doi.org/10.1007/s11069015-1597-X

Shi Y. (2013). Population vulnerability assessment based on scenario simulation of 
rainstorm-induced waterlogging: a case study of Xuhui District, Shanghai City. Natural Hazards, 66(2), 1189-1203. https://dx.doi.org/10.1007/s11069-012$\underline{0544-3}$

Shi Y, Xu S-Y, \& Shi C. (2011). Progress in research on vulnerability of natural disasters. Journal of Natural Disasters, 20(02), 131-137. https://dx.doi.org/10.13577/j.jnd.2011.0221

Spitalar M, Gourley JJ, Lutoff C, Kirstetter PE, Brilly M, \& Carr N. (2014). Analysis of flash flood parameters and human impacts in the US from 2006 to 2012. Journal of Hydrology, 519, 863-870. https://doi.org/10.1016/j.jhydrol.2014.07.004

Susan L, \& Cutter. (2003). Social Vulnerability to Environmental Hazards. Social Science Quarterly. https://dx.doi.org/10.1111/1540-6237.8402002

Tanoue M, Hirabayashi Y, \& Ikeuchi H. (2016). Global-scale river flood vulnerability in the last 50 years. Scientific Reports, 6, 9. https://dx.doi.org/10.1038/srep36021

Tehrany MS, Pradhan B, \& Jebur MN. (2013). Spatial prediction of flood susceptible areas using rule based decision tree (DT) and a novel ensemble bivariate and multivariate statistical models in GIS. Journal of Hydrology, 504, 69-79. https://dx.doi.org/10.1016/j.jhydrol.2013.09.034

Tehrany MS, Pradhan B, \& Jebur MN. (2014). Flood susceptibility mapping using a novel ensemble weights-of-evidence and support vector machine models in GIS. Journal of Hydrology, 512(6), 332-343. https://dx.doi.org/10.1016/j.jhydrol.2014.03.008

Tehrany MS, Pradhan B, Mansor S, \& Ahmad N. (2015). Flood susceptibility assessment using GIS-based support vector machine model with different kernel types. Catena, 125, 91-101. https://dx.doi.org/10.1016/j.catena.2014.10.017

Wan SA, \& Lei TC. (2009). A knowledge-based decision support system to analyze the debris-flow problems at Chen-Yu-Lan River, Taiwan. Knowledge-Based Systems, 22(8), 580-588. https://dx.doi.org/10.1016/j.knosys.2009.07.008

Weis SWM, Agostini VN, Roth LM, et al. (2016). Assessing vulnerability: an integrated approach for mapping adaptive capacity, sensitivity, and exposure. Climatic Change, 136(3), 615-629. https://dx.doi.org/10.1007/s10584-016-1642-0

Werren G, Reynard E, Lane SN, \& Balin D. (2016). Flood hazard assessment and mapping in semi-arid piedmont areas: a case study in Beni Mellal, Morocco. Natural Hazards, 81(1), 481-511. https://dx.doi.org/10.1007/s11069-015-2092$\underline{0}$

Wu J, Yang R, \& Song J. (2018). Effectiveness of low-impact development for urban inundation risk mitigation under different scenarios: a case study in Shenzhen, China. NATURAL HAZARDS AND EARTH SYSTEM SCIENCES, 18(9), 2525-2536. https://dx.doi.org/10.5194/nhess-18-2525-2018

Xia F-Q, Kang X-W, Wu S-H, et al. (2008). Research on dike breach risk of the hanging 
reach under different flood conditions in the Lower Yellow River. Geographical Research, 27(1), 229-239. https://dx.doi.org/10.1016/S1005-8885(08)60096-5

Xian S-D. (2010). A new fuzzy comprehensive evaluation model based on the support vector machine. Fuzzy Information Engineering, 2(1), 75-86. https://dx.doi.org/10.1007/s12543-010-0038-5

Xiong J-N, Li J, Cheng W-M, Wang N, \& Guo L. (2019). A GIS-Based Support Vector Machine Model for Flash Flood Vulnerability Assessment and Mapping in China. International Journal of Geo-Information, 8(7), 297. https://dx.doi.org/10.3390/ijgi8070297

Xiong J-N, Sun M, Zhang H, et al. (2019). Application of the Levenburg-Marquardt back propagation neural network approach for landslide risk assessments. NATURAL HAZARDS AND EARTH SYSTEM SCIENCES, 19(3), 629-653. https://dx.doi.org/10.5194/nhess-19-629-2019

$\mathrm{Xu} \mathrm{C}$, Dai F-C, Xu X-W, \& Lee YH. (2012). GIS-based support vector machine modeling of earthquake-triggered landslide susceptibility in the Jianjiang River watershed, China. Geomorphology, 145-146, 70-80. https://dx.doi.org/10.1016/j.geomorph.2011.12.040

Yang X-L, Ding J-H, \& Hou H. (2013). Application of a triangular fuzzy AHP approach for flood risk evaluation and response measures analysis. Natural Hazards, 68(2), 657-674. https://dx.doi.org/10.1007/s11069-013-0642-x

Yao X, Tham LG, \& Dai F-C. (2008). Landslide susceptibility mapping based on Support Vector Machine: A case study on natural slopes of Hong Kong, China. Geomorphology, 101(4), 572-582. https://dx.doi.org/10.1016/j.geomorph.2008.02.011

Zhang J-D. (2018). The Current Situation of the One Belt and One Road Initiative and Its Development Trend. In Rong WZhu C-P (Eds.), Annual Report on the Development of the Indian Ocean Region (2017): The Belt and Road Initiative and South Asia (pp. 103-137). Singapore: Springer Singapore.

Zhang Y-L, \& You W-J. (2014). Social vulnerability to floods: a case study of Huaihe River Basin. Natural Hazards, 71(3), 2113-2125. https://dx.doi.org/10.1007/s11069-013-0996-0

Zhang Z-G. (2014). Research on rainstorm waterlogging risk assessment of urban comminities_a case of Jinsha community, Shanghai. Shanghai Normal University.

Zhou J, Jiang T, Wang Y-J, Su B-D, \& Zhai J-Q. (2020). Spatiotemporal variations of aridity index over the Belt and Road region under the $1.5^{\circ} \mathrm{C}$ and $2.0^{\circ} \mathrm{C}$ warming scenarios. Journal of Geographical ences, 30(1), 37-52. https://dx.doi.org/10.1007/s11442-020-1713-Z

Zhou S-E, Zhang M-J, \& Wang S-J. (2018). Assessment of vulnerability in naturalsocial system in Hexi, Gansu. Resources Science, 40(2), 452-462. https://dx.doi.org/10.18402/resci.2018.02.20 
Zhou Y, Li N, Wu W-X, \& Wu J-D. (2014). Assessment of provincial social vulnerability to natural disasters in China. Natural Hazards, 71(3), 2165-2186. https://dx.doi.org/10.1007/s11069-013-1003-5

Zong N. (2013). Flood hazard vulnerability and risk assessment of urban community-A case study of Shanghai. East China Normal University. 
Table 1 Sources and resolutions of the datasets

941 Table 2 Linguistic variables and the corresponding triangular fuzzy numbers

942 Table 3 Judgment matrix and normalized weights of the exposure indexes

943 Table 4 Exposure of floods for the grid cells throughout the Belt and Road region

944 Table 5 Disaster reduction capability of floods for the grid cells throughout the Belt and Road region

945 Table 6 Vulnerability of floods for the grid cells throughout the Belt and Road region

947 Fig. 1 Location of the Belt and Road region

948 Fig. 2 Flood vulnerability assessment index system for the Belt and Road region

949 Fig. 3 Flowchart of the flood vulnerability assessment throughout the Belt and Road region

950 Fig. 4 Spatial distribution of the exposure throughout the Belt and Road region

951 Fig. 5 Spatial distribution of the disaster reduction capability throughout the Belt and Road region

952 Fig. 6 Spatial distribution of the vulnerability throughout the Belt and Road region 
Table 2 Sources and resolutions of the datasets

\begin{tabular}{cccc}
\hline Factors & Source & Resolution & Type, Timeframe \\
\hline Population & World Pop & $1 \times 1 \mathrm{~km}$ & raster data, 2015 \\
\hline Land use & National Aeronautics and Space & & \\
& Administration (NASA) & $0.5 \times 0.5 \mathrm{~km}$ & vector data, 2015 \\
\hline GDP & Dryad & 5 arc-min & raster data, 2015 \\
\hline Infrastructure & OpenStreetMap & $1: 50,000$ & vector data, 2015 \\
\hline DEM & SRTM Data & $1 \times 1 \mathrm{~km}$ & raster data, 2010 \\
\hline Impervious surface & Global Human Settlement Layer & $30 \times 30 \mathrm{~m}$ & raster data, 2014 \\
\hline
\end{tabular}

Table 2 Linguistic variables and the corresponding triangular fuzzy numbers

\begin{tabular}{cccc}
\hline Linguistic Terms & $\begin{array}{c}\text { Intensity } \\
\text { Importance }\end{array}$ & $\begin{array}{c}\text { Triangular } \\
\text { Fuzzy Numbers }\end{array}$ & $\begin{array}{c}\text { Reciprocal Triangular } \\
\text { Fuzzy Numbers }\end{array}$ \\
\hline Equal importance & 1 & $(1,1,1)$ & $(1,1,1)$ \\
Almost equal importance & 1 & $(1,1,3)$ & $(1 / 3,1,1)$ \\
Intermediate value & 2 & $(1,2,4)$ & $(1 / 4,1 / 2,1)$ \\
Moderate importance & 3 & $(1,3,5)$ & $(1 / 5,1 / 3,1)$ \\
Intermediate value & 4 & $(2,4,6)$ & $(1 / 6,1 / 4,1 / 2)$ \\
Strong importance & 5 & $(3,5,7)$ & $(1 / 7,1 / 5,1 / 3)$ \\
Intermediate value & 6 & $(4,6,8)$ & $(1 / 8,1 / 6,1 / 4)$ \\
Very strong importance & 7 & $(5,7,9)$ & $(1 / 9,1 / 7,1 / 5)$ \\
Intermediate value & 8 & $(6,8,10)$ & $(1 / 11,1 / 9,1 / 7)$ \\
Extreme importance & 9 & $(7,9,11)$ &
\end{tabular}


Table 3 Judgment matrix and normalized weights of the exposure indexes

\begin{tabular}{cccccc}
\hline Exposure & FAD & BUD & ECD & POD & Normalized \\
& & & & & Weights \\
\hline FAD & $(1,1,1)$ & $(0.5,1,1)$ & $(0.2,0.333,1)$ & $(0.143,0.2,0.333)$ & 0.032 \\
BUD & $(1,1,2)$ & $(1,1,1)$ & $(0.333,0.5,1)$ & $(0.2,0.25,0.5)$ & 0.110 \\
ECD & $(1,3,5)$ & $(1,2,3)$ & $(1,1,1)$ & $(0.25,0.5,1)$ & 0.346 \\
POD & $(3,5,7)$ & $(2,4,5)$ & $(1,2,4)$ & $(1,1,1)$ & 0.512 \\
\hline
\end{tabular}

Note: FAD is the farmland density; BUD is the building density; ECD is the economic density; and POD

Table 4 Exposure of floods for the grid cells throughout the Belt and Road region

\begin{tabular}{cccc}
\hline \multirow{2}{*}{ Type } & \multicolumn{3}{c}{ Exposure } \\
\cline { 2 - 4 } & Count & Area/10000 $\mathbf{~ k m}^{\mathbf{2}}$ & Ratio (\%) \\
\hline Extremely low & 558632 & 4378.15 & 86.45 \\
Low & 44006 & 344.62 & 6.81 \\
Moderate & 25977 & 203.57 & 4.02 \\
High & 13053 & 102.11 & 2.02 \\
Extremely high & 4523 & 35.59 & 0.70 \\
\hline
\end{tabular}


Table 5 Disaster reduction capability of floods for the grid cells throughout the Belt and Road region

\begin{tabular}{cccc}
\hline \multirow{2}{*}{ Type } & \multicolumn{3}{c}{ Disaster Reduction Capability } \\
\cline { 2 - 4 } & Count & Area/10000 k $\mathbf{~ m}^{\mathbf{2}}$ & Ratio (\%) \\
\hline Extremely low & 520377 & 4078.53 & 80.53 \\
Low & 100418 & 786.92 & 15.54 \\
Moderate & 21065 & 164.94 & 3.26 \\
High & 3683 & 28.72 & 0.57 \\
Extremely high & 648 & 4.93 & 0.10 \\
\hline
\end{tabular}

964

965 Table 6 Vulnerability of floods for the grid cells throughout the Belt and Road region

\begin{tabular}{cccc}
\hline \multirow{2}{*}{ Type } & \multicolumn{3}{c}{ Vulnerability } \\
\cline { 2 - 4 } & Count & Area/10000 k $\mathbf{~ m}^{\mathbf{2}}$ & Ratio (\%) \\
\hline Extremely low & 559149 & 4381.75 & 86.53 \\
Low & 41938 & 328.78 & 6.49 \\
Moderate & 22229 & 174.42 & 3.44 \\
High & 15767 & 123.61 & 2.44 \\
Extremely high & 7108 & 55.48 & 1.10 \\
\hline
\end{tabular}

966 


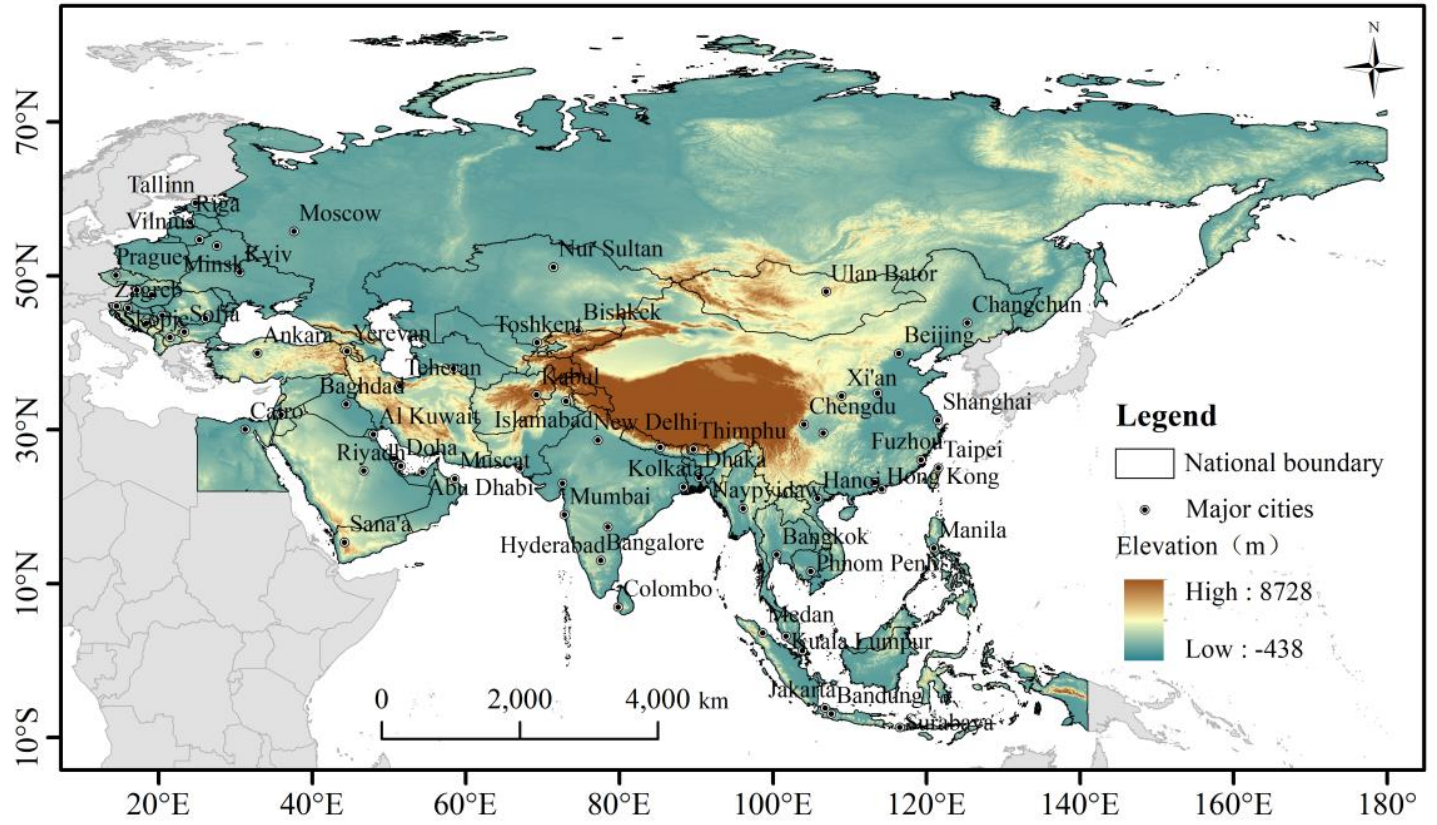

Fig. 3 Location of the Belt and Road region

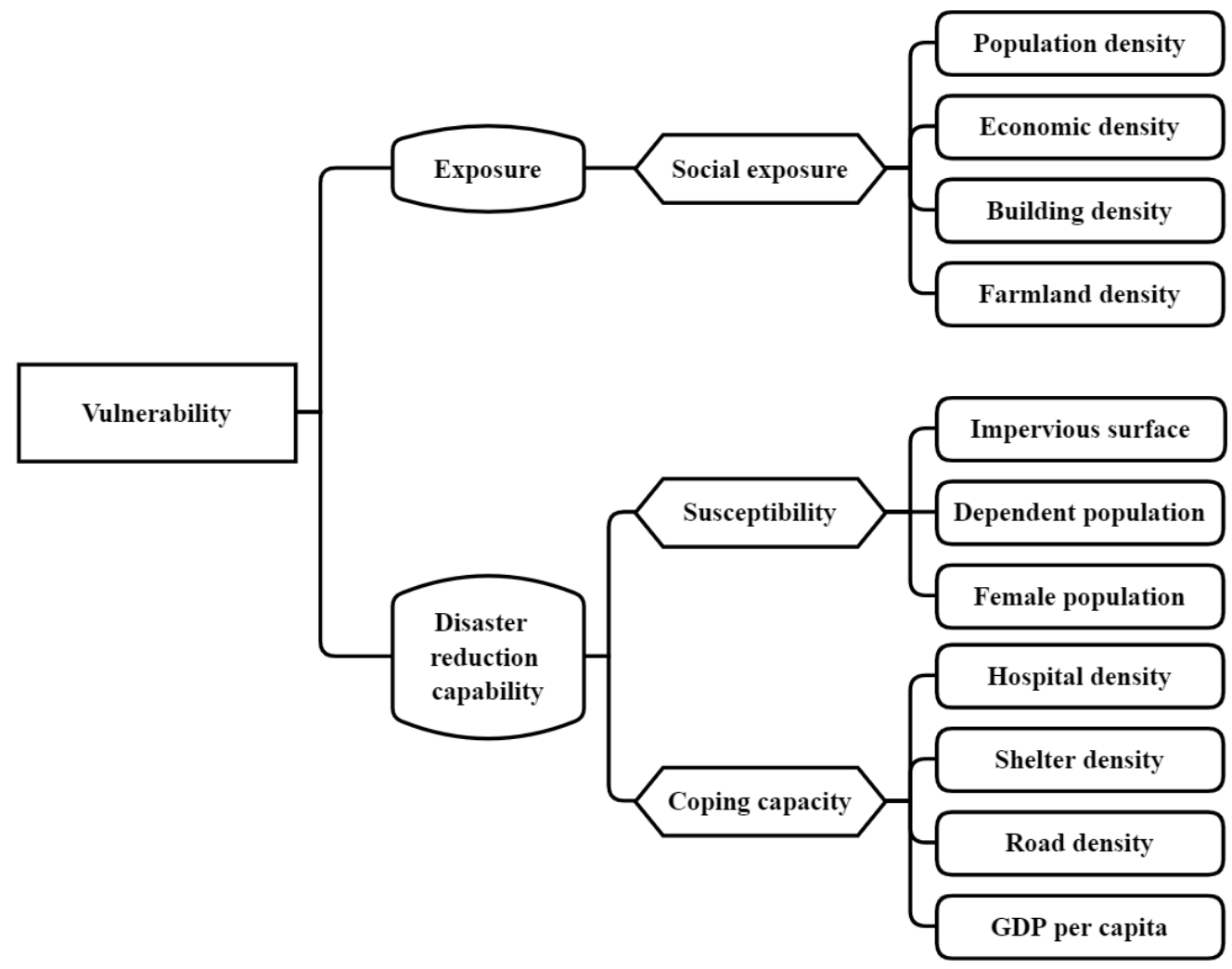

Fig. 1 Flood vulnerability assessment index system for the Belt and Road region 


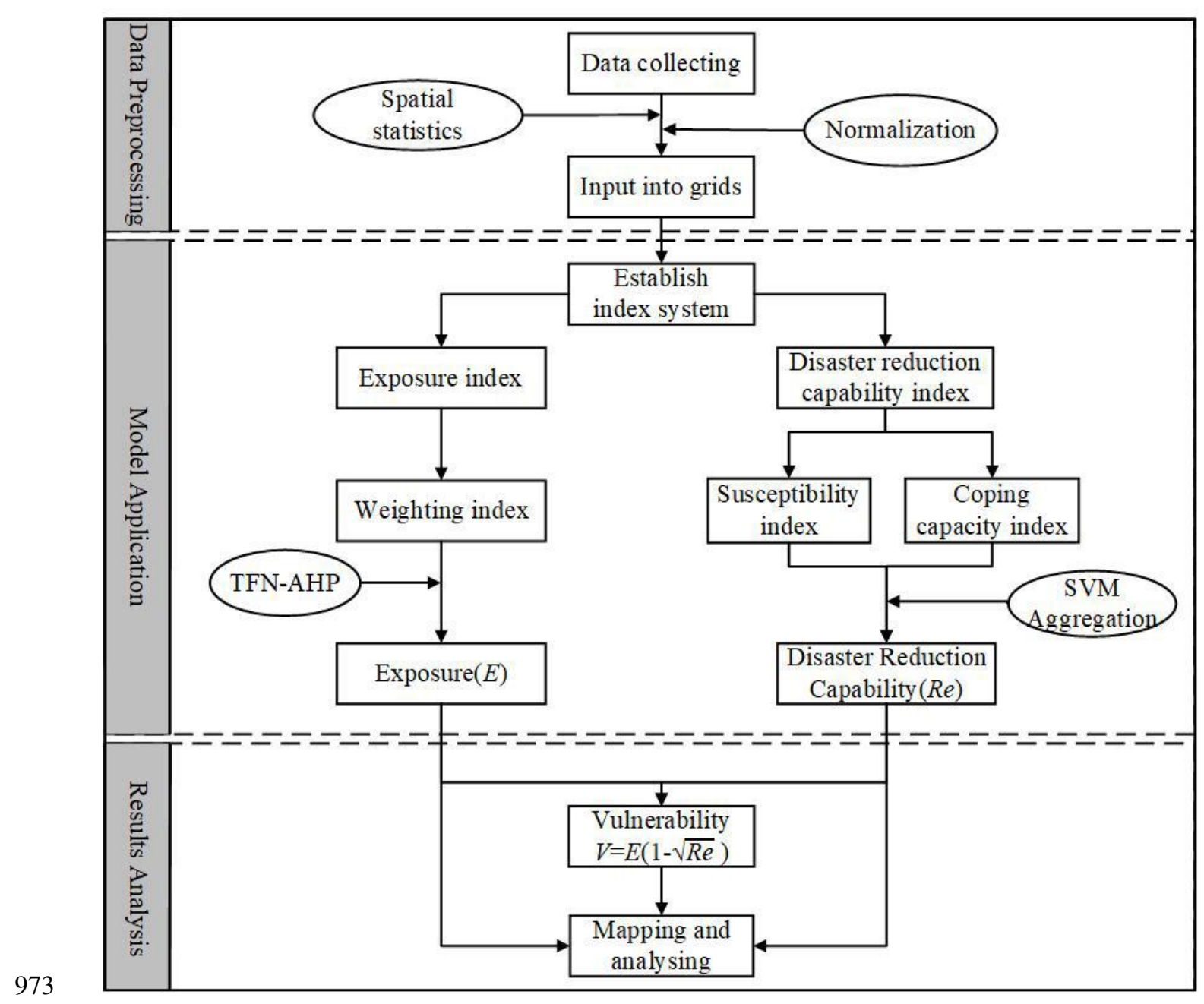

974 Fig. 2 Flowchart of the flood vulnerability assessment throughout the Belt and Road region 


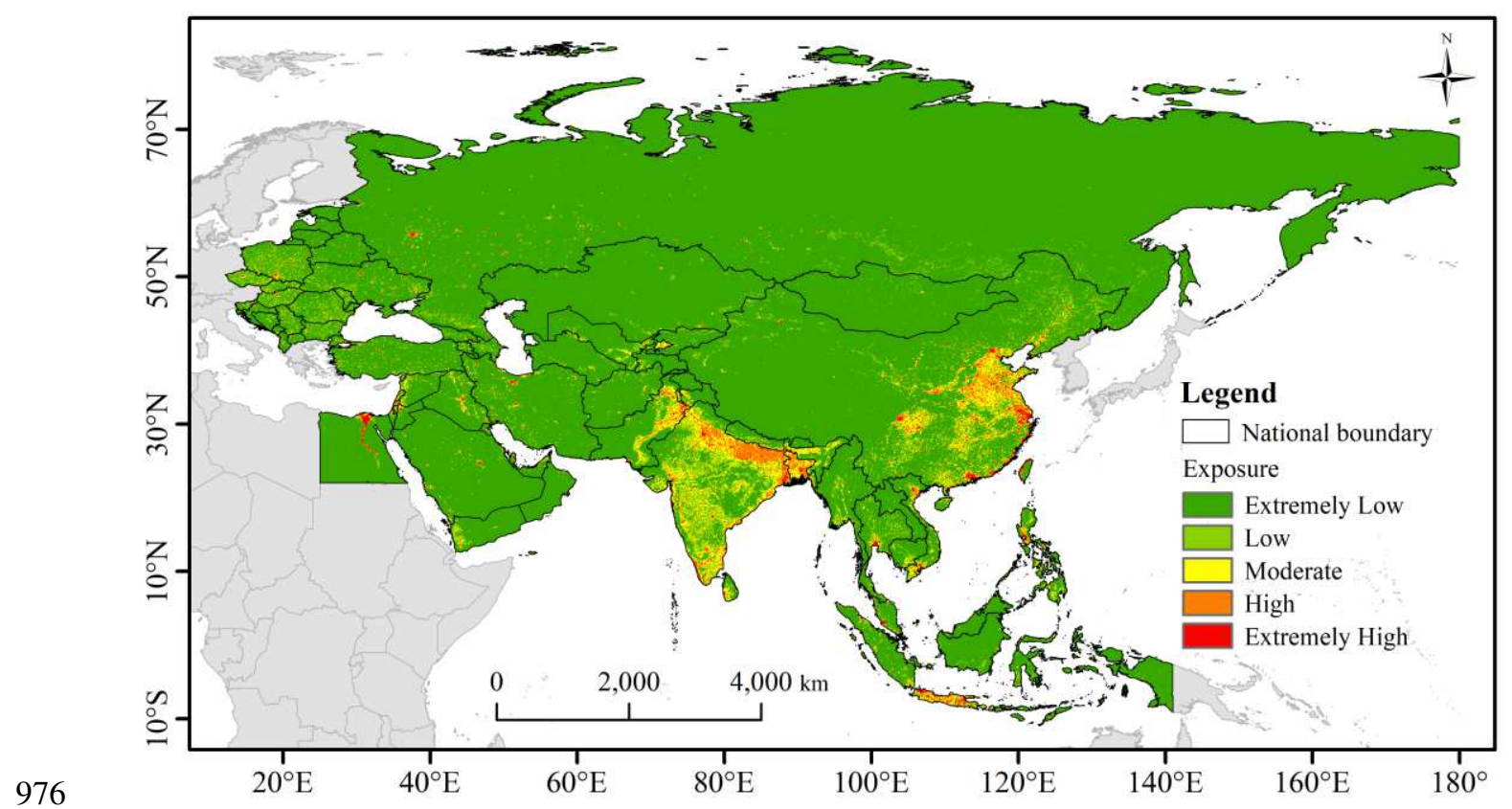

Fig. 3 Spatial distribution of the exposure throughout the Belt and Road region

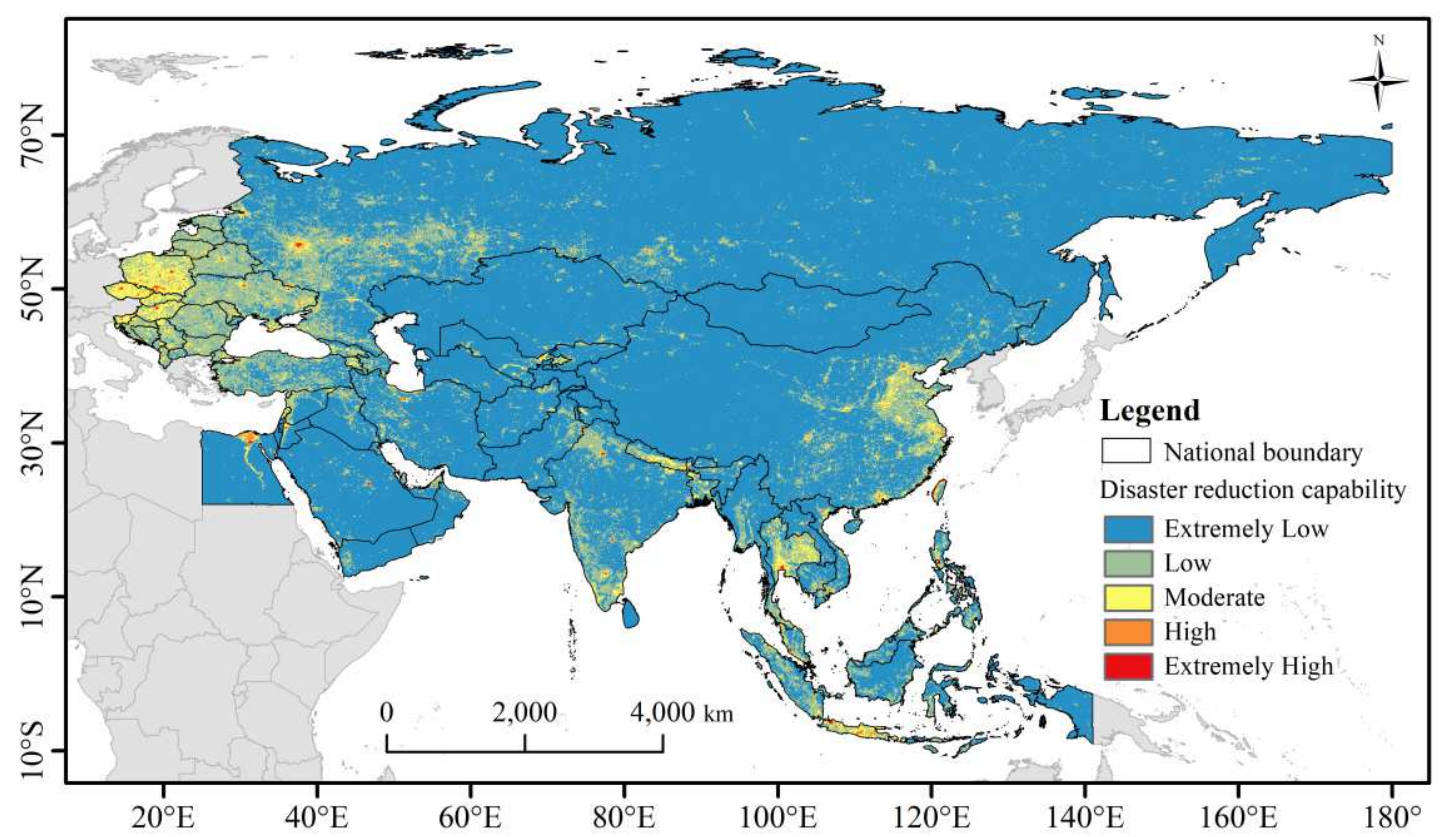

980 Fig. 4 Spatial distribution of the disaster reduction capability throughout the Belt and Road region 


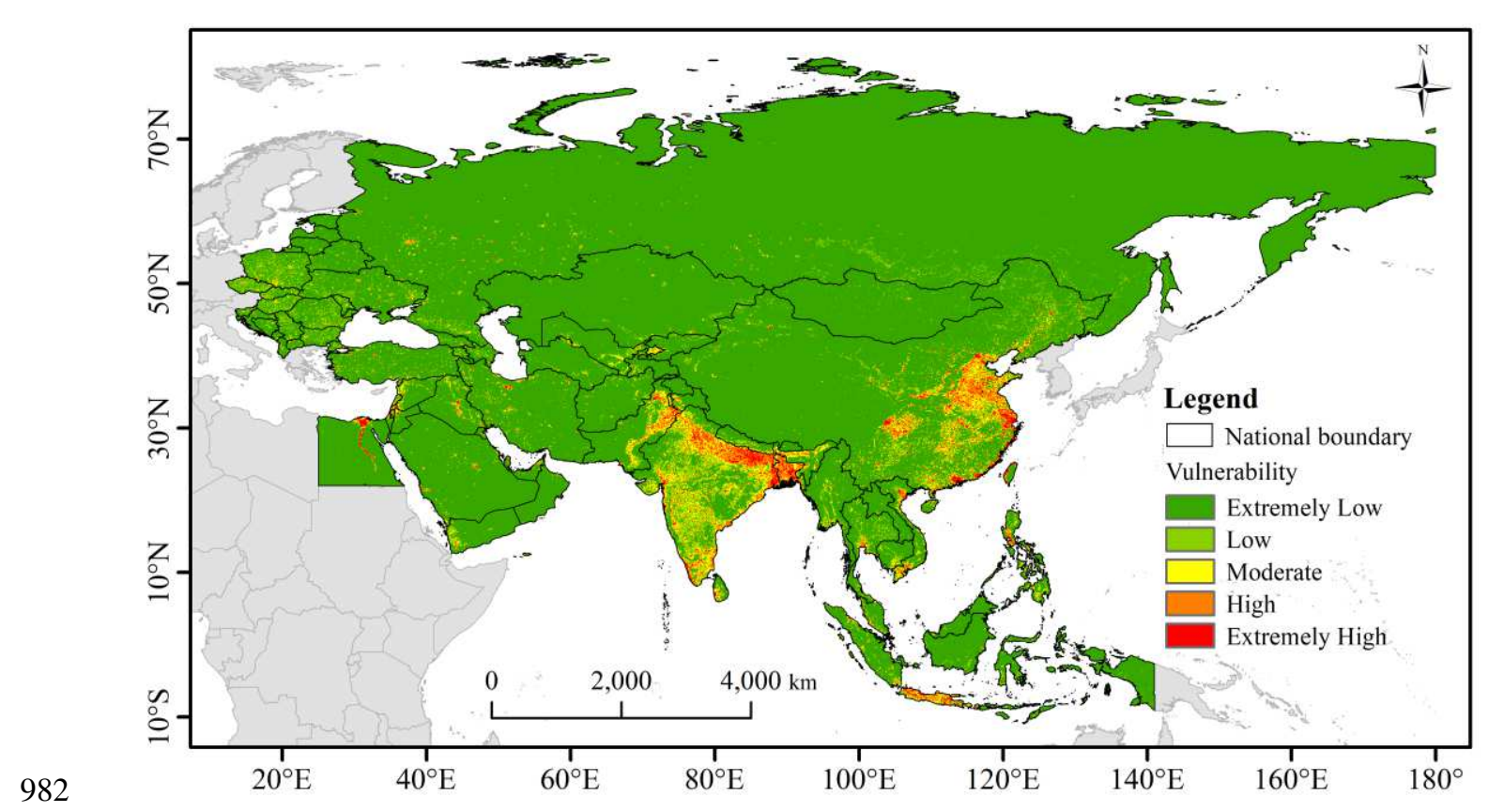

983 Fig. 5 Spatial distribution of the vulnerability throughout the Belt and Road region 


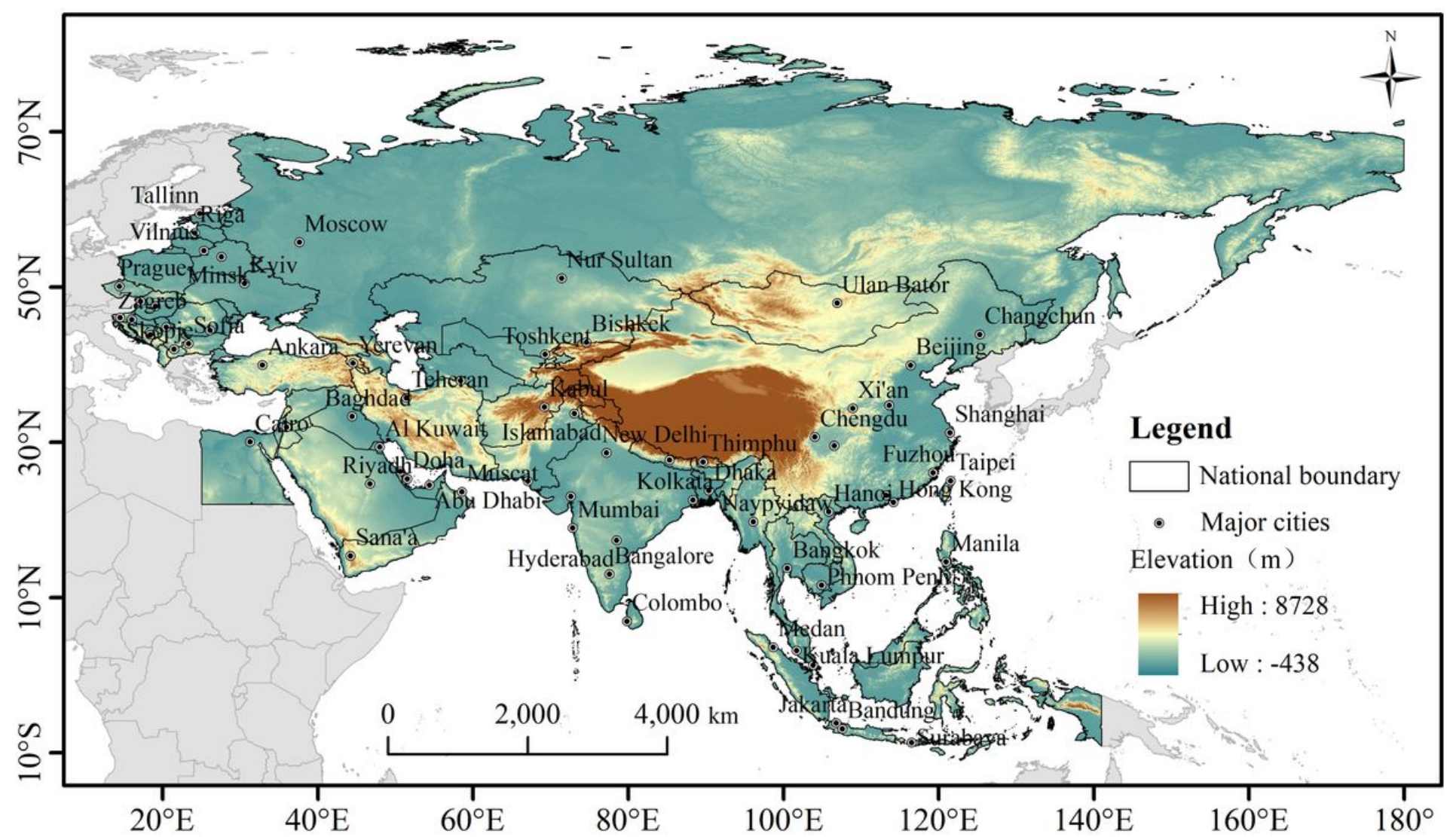

Figure 1

Location of the Belt and Road region. Note: The designations employed and the presentation of the material on this map do not imply the expression of any opinion whatsoever on the part of Research Square concerning the legal status of any country, territory, city or area or of its authorities, or concerning the delimitation of its frontiers or boundaries. This map has been provided by the authors. 


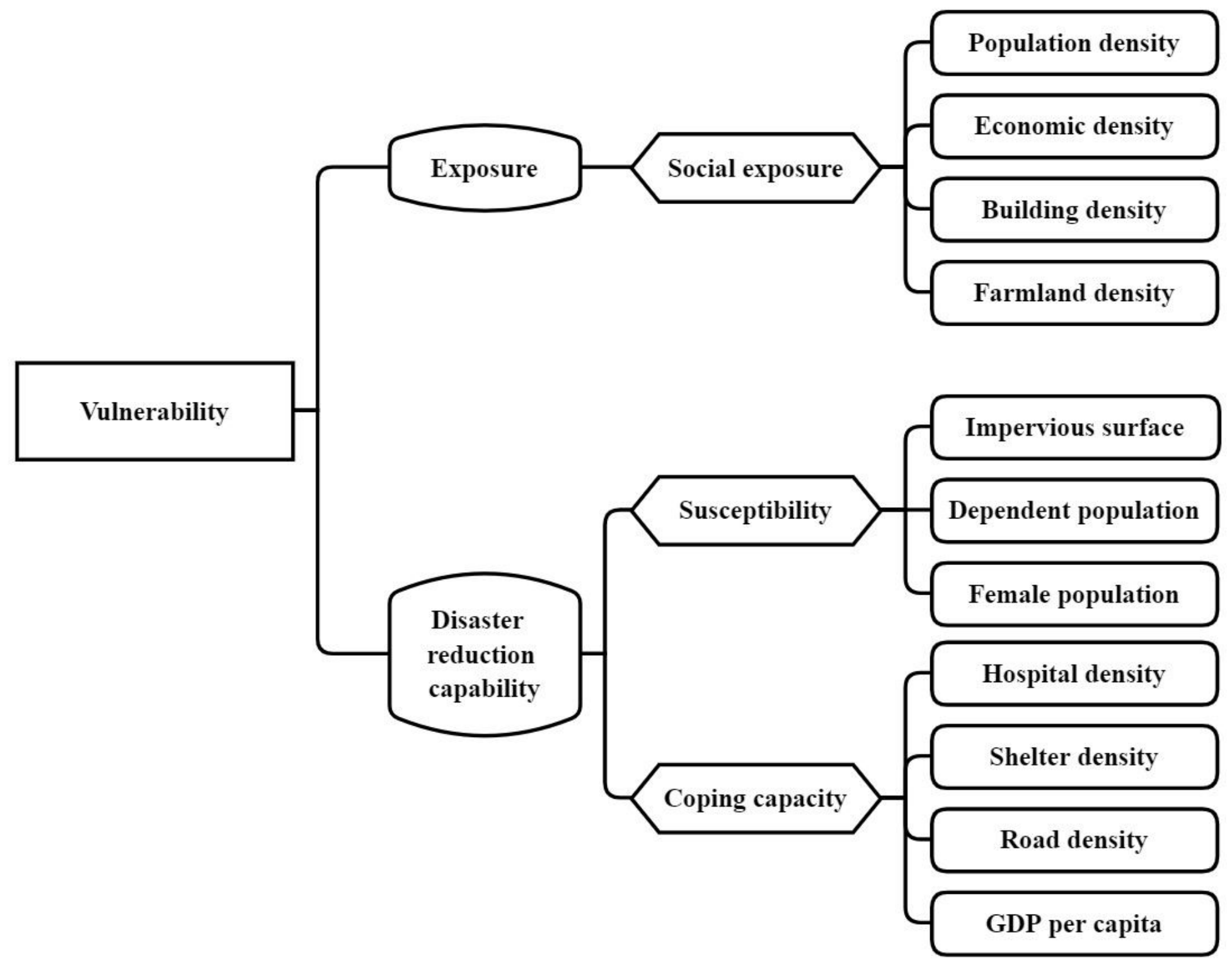

Figure 2

Flood vulnerability assessment index system for the Belt and Road region 


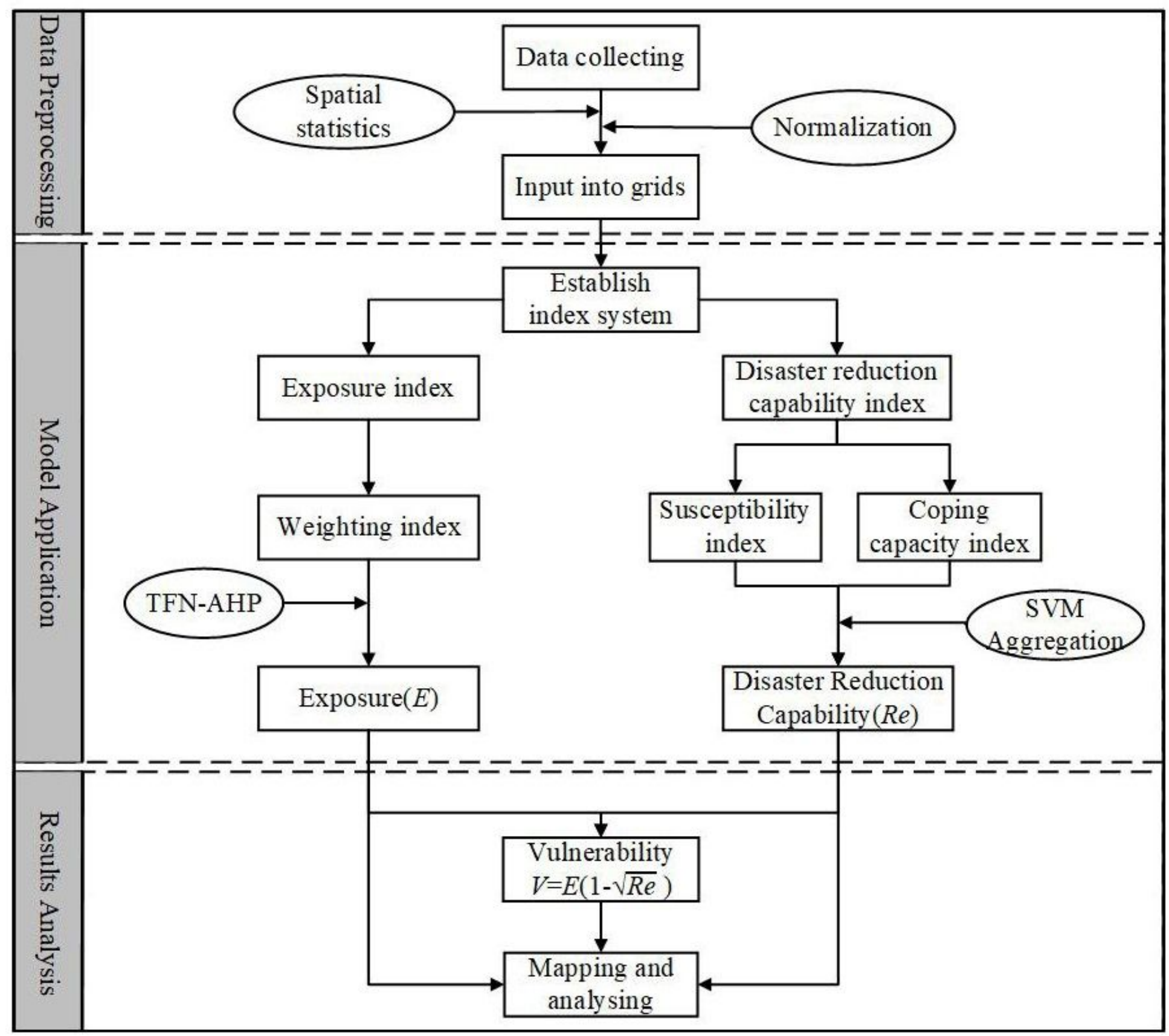

Figure 3

Flowchart of the flood vulnerability assessment throughout the Belt and Road region 


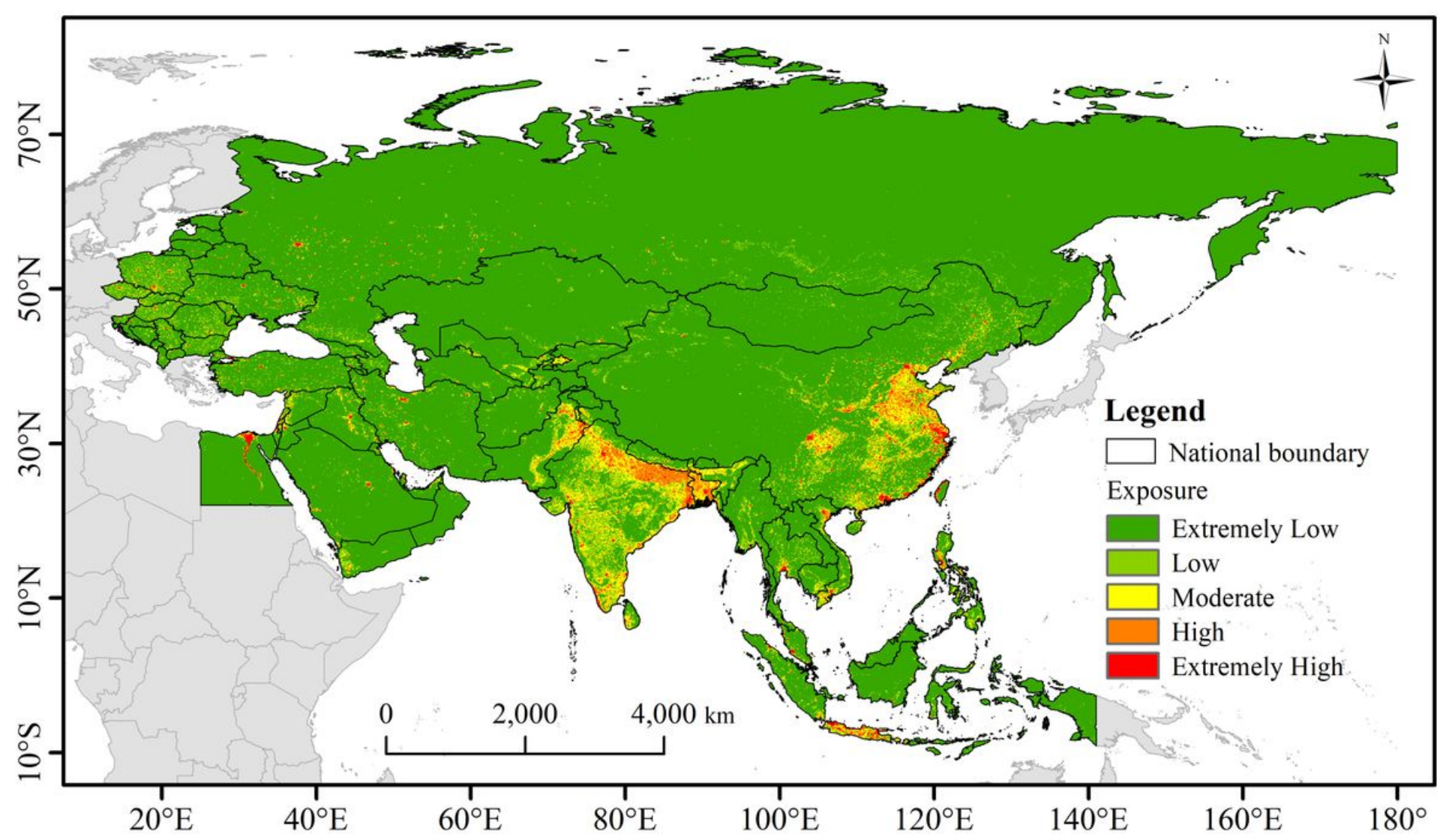

Figure 4

Spatial distribution of the exposure throughout the Belt and Road region. Note: The designations employed and the presentation of the material on this map do not imply the expression of any opinion whatsoever on the part of Research Square concerning the legal status of any country, territory, city or area or of its authorities, or concerning the delimitation of its frontiers or boundaries. This map has been provided by the authors. 


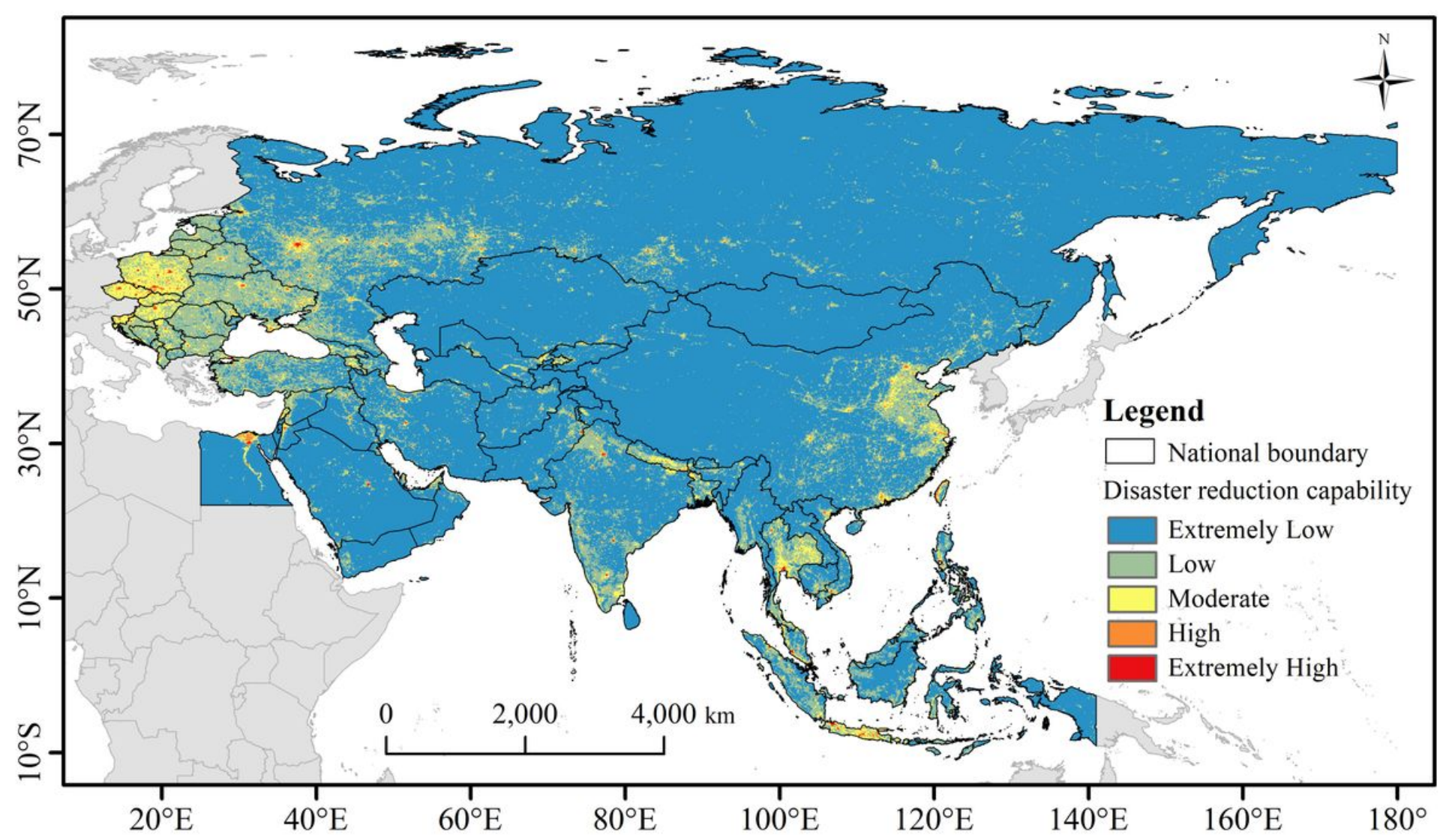

Figure 5

Spatial distribution of the disaster reduction capability throughout the Belt and Road region. Note: The designations employed and the presentation of the material on this map do not imply the expression of any opinion whatsoever on the part of Research Square concerning the legal status of any country, territory, city or area or of its authorities, or concerning the delimitation of its frontiers or boundaries. This map has been provided by the authors. 


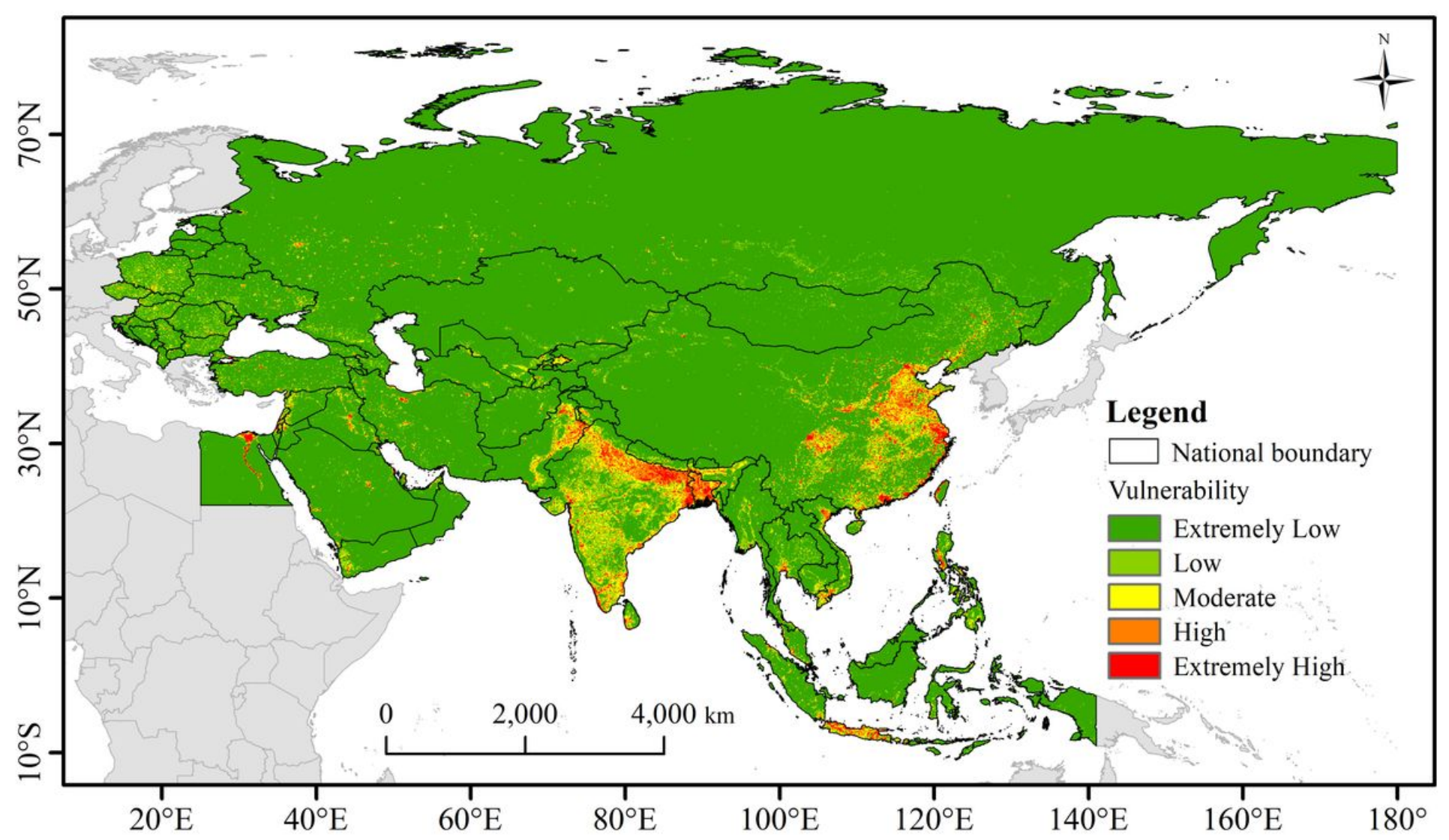

Figure 6

Spatial distribution of the vulnerability throughout the Belt and Road region. Note: The designations employed and the presentation of the material on this map do not imply the expression of any opinion whatsoever on the part of Research Square concerning the legal status of any country, territory, city or area or of its authorities, or concerning the delimitation of its frontiers or boundaries. This map has been provided by the authors. 